\title{
HIV Tat Impairs Neurogenesis through Functioning As a Notch Ligand and Activation of Notch Signaling Pathway
}

\author{
ㄱan Fan, ${ }^{1}$ @Xiang Gao, ${ }^{2}$ Jinhui Chen, ${ }^{2}$ Ying Liu, ${ }^{1}$ and $\odot$ Johnny J. $\mathrm{He}^{1}$ \\ 'Department of Cell Biology and Immunology, Graduate School of Biomedical Sciences, University of North Texas Health Science Center, Fort Worth, Texas \\ 76107, and 2Department of Neurosurgery, Indiana University School of Medicine, Indianapolis, Indiana 46202
}

\begin{abstract}
Alterations in adult neurogenesis have been noted in the brain of HIV-infected individuals and are likely linked to HIV-associated neurocognitive deficits, including those in learning and memory. But the underlying molecular mechanisms are not fully understood. In the study, we took advantage of doxycycline-inducible and astrocyte-specific HIV-1 Tat transgenic mice (iTat) and determined the relationship between Tat expression and neurogenesis. Tat expression in astrocytes was associated with fewer neuron progenitor cells (NPCs), fewer immature neurons, and fewer mature neurons in the dentate gyrus of the hippocampus of the mouse brain. In vitro NPC-derived neurosphere assays showed that Tat-containing conditioned media from astrocytes or recombinant Tat protein inhibited NPC proliferation and migration and altered NPC differentiation, while immunodepletion of Tat from Tat-containing conditioned media or heat inactivation of recombinant Tat abrogated those effects. Notch signaling downstream gene Hes1 promoter-driven luciferase reporter gene assay and Western blotting showed that recombinant Tat or Tat-containing conditioned media activated Hes 1 transcription and protein expression, which were abrogated by Tat heat inactivation, immunodepletion, and cysteine mutation at position 30. Last, Notch signaling inhibitor $N$-[ $N$-(3,5-difluorophenacetyl)-Lalanyl]-S-phenylglycine t-butyl ester (DAPT) significantly rescued Tat-impaired NPC differentiation in vitro and neurogenesis in vivo. Together, these results show that Tat adversely affects NPCs and neurogenesis through Notch signaling and point to the potential of developing Notch signaling inhibitors as HIV/neuroAIDS therapeutics.
\end{abstract}

Key words: HIV Tat; MCMD; neurogenesis; neuron progenitor cells; Notch ligand; Notch receptor

Significance Statement

HIV infection of the CNS causes cognitive and memory deficits, which have become more prevalent in the era of combination antiretroviral therapy (cART). Neurogenesis is impaired in HIV-infected individuals. But the underlying molecular mechanisms remain largely unknown. In this study, we have discovered that HIV Tat impairs neurogenesis through the Notch signaling pathway. These findings are particularly important because Tat protein has recently been detected in the brain of HIV-infected individuals with HIV replication in the periphery being effectively controlled by cART. The current study not only further highlights the importance of HIV Tat protein in HIV/neuroAIDS, but also presents a new strategy to develop novel HIV/neuroAIDS therapeutics, particularly in the era of cART.

\section{Introduction}

Neurogenesis is a highly regulated developmental process and involves proliferation, migration, differentiation, and maturation of neuron progenitor cells (NPCs). This process continues

Received April 11, 2016; revised Aug. 18, 2016; accepted Sept. 10, 2016.

Author contributions: Y.F., X.G., Y.L., J.C., and J.J.H. designed research; Y.F., X.G., Y.L., J.C., and J.J.H. performed research; Y.F., X.G., Y.L., J.C., and J.J.H. contributed unpublished reagents/analytic tools; Y.F., X.G., Y.L., J.C., and J.J.H. analyzed data; Y.F. and J.J.H. wrote the paper.

This work was supported in part by Grants NIH/NIDA R21DA029428, NIH/NINDS R01NS065785, NIH/NINDS R01NS094108, and NIH/NIMH R01MH092673 (to J.J.H.) from the National Institutes of Health. We thank Grigori Enikolopov of Cold Spring Harbor Laboratory for the nestin-GFP mice, and Dr. Nadia Carlesso of Indiana University School of Medicine for pHes1-Luc plasmid.

The authors declare no competing financial interests. throughout adult life in the subventricular zone of the lateral ventricle to generate interneurons in the olfactory bulb and in the subgranular zone of the dentate gyrus to generate granule cells in the hippocampus (Ming and Song, 2005; Lledo et al., 2006). Adult neurogenesis in the hippocampus is involved in maintenance of the cognitive functions, such as learning and memory, and is regulated by physiological and pathological stimuli (Fuchs and Gould, 2000; Ming and Song, 2005; Leuner et al., 2006).

Correspondence should be addressed to Johnny J. He, Department of Cell Biology and Immunology, Graduate School of Biomedical Sciences, University of North Texas Health Science Center, 3500 Camp Bowie Boulevard, Fort Worth, TX 76107. E-mail: johnny.he@unthsc.edu.

DOI:10.1523/JNEUROSCI.1208-16.2016

Copyright $\odot 2016$ the authors $\quad 0270-6474 / 16 / 3611362-12 \$ 15.00 / 0$ 
HIV infection of the CNS often leads to cognitive, motor, and neurobehavioral dysfunction (Epstein et al., 1986; Valcour et al., 2004; Dubé et al., 2005). In the era of combination antiretroviral therapy (cART), minor cognitive and motor disorder (MCMD) has become increasingly prevalent (Ellis et al., 1997; Kaul et al., 2001, 2005). Impaired neurogenesis has been noted in the hippocampus of $\mathrm{HIV}$-infected individuals, simian immunodeficiency virus-infected macaques, and severe combined immunodeficiency mice injected with HIV-infected human macrophages/microglia (Krathwohl and Kaiser, 2004a,b; Poluektova et al., 2005; Curtis et al., 2014). Several putative mechanisms are proposed for HIV-impaired neurogenesis. HIV infection of macrophages/microglia and astrocytes alters expression of cytokines or growth factors (Lee et al., 2002; Vallières et al., 2002; Sairanen et al., 2005; Iosif et al., 2006; Peng et al., 2008), several of which are known to affect adult hippocampal neurogenesis. HIV could have effects on NPCs through direct infection (Lawrence et al., 2004; Tran et al., 2005; Schwartz and Major, 2006; Whitney et al., 2009). HIV has been shown to inhibit proliferation and promote quiescence of NPCs (Krathwohl and Kaiser, 2004a; Okamoto et al., 2007) and NPC migration (Belmadani et al., 2005, 2006). HIV gp120 expression has been shown to inhibit NPC proliferation in vitro and in gp120-expressing transgenic mice (Okamoto et al., 2007). Currently, there have been no effective therapies to reduce, prevent, or reverse MCMD. Thus, a better understanding of the cellular and molecular mechanisms for HIV-impaired neurogenesis is needed.

HIV Tat protein is a major pathogenic factor in HIV/neuroAIDS, as its expression alone in the brain is sufficient to result in neuropathological and neurobehavioral changes reminiscent of those in HIV-infected individuals (Kim et al., 2003; Paris et al., 2014). HIV Tat is secreted from HIV-infected cells (Westendorp et al., 1995; Xiao et al., 2000) and taken up by uninfected cells (Frankel and Pabo, 1988; Mann and Frankel, 1991; Bonifaci et al., 1995; Liu et al., 2000). Tat transcripts are elevated in HIVdemented brain and Tat protein is detected in HIV-infected brain (Parmentier et al., 1992; Cupp et al., 1993; Kolson et al., 1993; Bratanich et al., 1998). Tat protein has been shown to affect mature neurons in a variety of ways (Chen et al., 1997; Cheng et al., 1998; Conant et al., 1998; Jones et al., 1998; Zidovetzki et al., 1998; Hofman et al., 1999) and inhibit NPC proliferation and differentiation in vitro (Mishra et al., 2010; Yao et al., 2012). Given the recent finding that Tat is persistently expressed in the brain of HIV-infected individuals treated with cART (Johnson et al., 2013), it is imperative to determine effects of Tat expression in neurogenesis and its contribution to HIV-associated MCMD.

In this study, we took advantage of the unique doxycyclineinducible and astrocyte-specific HIV-1 Tat transgenic mice (iTat) and the nestin promoter-driven green fluorescence protein mice (nestin-GFP) and assessed Tat effects during all stages of neurogenesis. In addition, we also attempted to delineate the molecular pathways involving Tat interaction with NPCs and neurogenesis.

\section{Materials and Methods}

Animals and tissues. Wild-type C57BL/6 mice (WT) were purchased from the Jackson Laboratory. Doxycycline (Dox)-inducible astrocytespecific HIV-1 Tat transgenic mice (iTat) were created in our laboratory as described previously (Kim et al., 2003; Zou et al., 2007). Nestin promoter-driven green fluorescence protein transgenic mice (nestinGFP) were obtained from Dr. Grigori Enikolopov of Cold Spring Harbor Laboratory, Cold Spring Harbor, New York (Mignone et al., 2004). iTat/ nestin-GFP mice were generated by cross breeding nestin-GFP mice with iTat mice. In vivo NPC proliferation was determined as described previously (Okamoto et al., 2007). Briefly, 4 -week-old mice ( $n=6$ each group; 3 male, 3 female) were intraperitoneally injected with Dox $[80 \mathrm{mg} / \mathrm{kg} / \mathrm{d}$ in double-distilled $\mathrm{H}_{2} \mathrm{O}$ ( $\left.\mathrm{ddH}_{2} \mathrm{O}\right)$, $\mathrm{pH}$ 2.8; Sigma-Aldrich] for $3 \mathrm{~d}$ and Dox plus bromodeoxyridine (BrdU; $50 \mathrm{mg} / \mathrm{kg} / \mathrm{d}$ in $\mathrm{ddH}_{2} \mathrm{O}$; Sigma-Aldrich) for $4 \mathrm{~d}$. Mouse brains were collected $24 \mathrm{~h}$ after the final injection and sectioned for floating staining. In vivo neurogenesis was determined as described previously (Chen et al., 2004). Briefly, 8 -week-old mice $(n=6$ each group; 3 male, 3 female) were intraperitoneally injected with Dox ( $80 \mathrm{mg} / \mathrm{kg} / \mathrm{d}$ in $\left.\mathrm{dd}_{2} \mathrm{O}, \mathrm{pH} 2.8\right)$ for $3 \mathrm{~d}$, Dox plus BrdU $(50 \mathrm{mg} / \mathrm{kg} / \mathrm{d}$ in $\mathrm{ddH}_{2} \mathrm{O}$ ) for $4 \mathrm{~d}$, and BrdU alone for $3 \mathrm{~d}$. Mouse brains were collected $25 \mathrm{~d}$ after the final injection and sectioned for floating staining. For in vivo neurogenesis involving Notch inhibitor $N$-[N-(3,5-difluorophenacetyl)L-alanyl]-S-phenylglycine t-butyl ester (DAPT; Cristofaro et al., 2013), DAPT ( $120 \mathrm{mg} / \mathrm{kg} / \mathrm{d}$ in $5 \%$ ethanol $/ 95 \%$ corn oil; ApexBio) was cointraperitoneally injected with Dox for $3 \mathrm{~d}$ and Dox, DAPT plus BrdU for $4 \mathrm{~d}$, and BrdU alone for $3 \mathrm{~d}$.

Cells and cell cultures. We purchased 293T cells from the American Tissue Culture Collection. These were maintained in DMEM (SigmaAldrich), supplemented with $10 \%$ fetal bovine serum (FBS; Atlanta Biologicals), $50 \mathrm{U} / \mathrm{ml}$ penicillin, and $50 \mu \mathrm{g} / \mathrm{ml}$ streptomycin in a $37^{\circ} \mathrm{C}, 5 \%$ $\mathrm{CO}_{2}$ incubator. Human primary astrocytes were isolated from a 6-weekold aborted human fetus as described previously (Liu et al., 2014). Mouse primary astrocytes were isolated from the embryonic day (E) 18.5 brain and induced to express Tat as described previously (Zhou et al., 2004). Primary astrocytes were cultured in F12-K medium (Cellgro) containing $10 \% \mathrm{FBS}, 50 \mathrm{U} / \mathrm{ml}$ penicillin, and $50 \mu \mathrm{g} / \mathrm{ml}$ streptomycin in a $37^{\circ} \mathrm{C}, 5 \%$ $\mathrm{CO}_{2}$ incubator. Cells were passaged every $3 \mathrm{~d}$. Mouse neuron progenitor cells (NPCs) were isolated from neonatal mouse pups (postnatal day 1 ; Xie et al., 2014). Briefly, brains were dissected and trypsinized into single cells by using TrypLE (Invitrogen). Cells were seeded in nontreated plates and maintained in the NPC medium: Neurobasal-A medium (Invitrogen) supplemented with $1 \%$ B27, $20 \mathrm{ng} / \mathrm{ml} \mathrm{EGF,} 20 \mathrm{ng} / \mathrm{ml} \mathrm{bFGF}, 50 \mathrm{U} / \mathrm{ml}$ penicillin, and $50 \mu \mathrm{g} / \mathrm{ml}$ streptomycin in a $37^{\circ} \mathrm{C}, 5 \% \mathrm{CO}_{2}$ incubator. NPCs began to form neurospheres after $7 \mathrm{~d}$ and were passaged every $7 \mathrm{~d}$.

Plasmids and transfection. pcDNA3 and pCMV- $\beta$-gal plasmids were purchased from Clontech. pTat.Myc was previously described (Liu et al., 2002). pHes1-Luc plasmid was kindly provided by Dr. Nadia Carlesso of the Indiana University School of Medicine. pLTR-Luc [donated by Drs. R. Jeeninga and B. Berkhout (Klaver and Berkhout, 1994; Jeeninga et al., 2000)] and pE-Tat.BL43.CC, pE-Tat.BL43.CS, and pE-Tat.BL43.SS [donated by Dr. Udaykumar Ranga (Ranga et al., 2004; Mishra et al., 2008)] were obtained through the National Institutes of Health (NIH) AIDS Reagent Program. For transfection, cells were plated in a $60 \mathrm{~mm}$ dish at a density of $1 \times 10^{6}$ cells/dish or in a 24-well plate at a density of $1 \times 10^{5}$ cells/well, cultured for $24 \mathrm{~h}$, and then transfected with plasmids $(8 \mu \mathrm{g}$ per $60 \mathrm{~mm}$ dish or $0.8 \mu \mathrm{g}$ per well) using standard calcium phosphate precipitation methods. Cells were harvested for protein analysis $72 \mathrm{~h}$ after transfection.

In vitro NPC proliferation assay. In vitro NPC proliferation assay was performed essentially as described previously (Mishra et al., 2010). Briefly, neurospheres derived from NPCs at the seventh day of cultures were trypsinized into single cells by using TrypLE (Thermo Fisher Scientific). Those cells were plated in a nontreated 12-well plate (Corning) at a density of $2 \times 10^{5}$ cells/well and cultured in the presence of Tatcontaining conditioned media or recombinant Tat protein (NIH AIDS Reagents Program; donated by Division of AIDS, National Institute of Allergy and Infectious Diseases) for $7 \mathrm{~d}$. Images of the neurospheres were taken using a Nikon Eclipse Ti microscope, and the diameters of the neurospheres were measured and analyzed using a NIS-Elements viewer 4.20 software (Nikon). For comparison, neurospheres were separated into two groups (Mishra et al., 2010): small neurospheres (diameter, $<60$ $\mu \mathrm{m})$ and large neurospheres (diameter, $>60 \mu \mathrm{m}$ ).

In vitro NPC migration assay. In vitro NPC migration assay was performed as previously described (Moors et al., 2007; Huang et al., 2012). Briefly, neurospheres derived from NPCs at the seventh day were treated with $5 \mu \mathrm{g} / \mathrm{ml}$ mitomycin C (Sigma-Aldrich) for $2 \mathrm{~h}$ (Shikatani et al., 2012), plated on a poly-lysine-coated 24-well plate (Corning), and cultured in the presence of Tat-containing conditioned media or recombinant Tat protein for $16 \mathrm{~h}$. Thirty neurospheres were randomly selected from each sample. Images of those neurospheres were taken. The dis- 
tance from the edge of each neurosphere to the farthest migrated cells was measured as the migration distance.

In vitro NPC differentiation assay. In vitro NPC differentiation assay was performed as described previously with some modifications. Briefly, neurospheres derived from NPCs at the seventh day were plated on a poly-lysine-coated coverslips in a 24 -well plate (Corning) or a polylysine-coated $6 \mathrm{~cm}$ plate, and cultured in the presence of Tat-containing conditioned media or recombinant Tat protein for $7 \mathrm{~d}$. The cells were processed for immunofluorescence staining (from a 24 -well plate) or harvested for Western blotting (from a $6 \mathrm{~cm}$ plate).

Preparation of Tat-containing conditioned media. Mouse primary astrocytes were isolated from iTat or WT mice, cultured in the presence of $\operatorname{Dox}(5 \mu \mathrm{g} / \mathrm{ml})$ for $3 \mathrm{~d}$, thoroughly rinsed with PBS three times to remove Dox and FBS, refilled with NPC culture medium described above or NPC differentiation medium (Neurobasal-A medium supplemented with $2 \%$ FBS, $50 \mathrm{U} / \mathrm{ml}$ penicillin, and $50 \mu \mathrm{g} / \mathrm{ml}$ streptomycin), and continued to culture for $24 \mathrm{~h}$. The supernatants were collected as Tat-containing conditioned media. Alternatively, human primary astrocytes were transfected with pcDNA3 or pTat.Myc, cultured for $16 \mathrm{~h}$, thoroughly rinsed with PBS three times, refilled with NPC culture medium or NPC differentiation medium described above, and continued to culture for $48 \mathrm{~h}$. The supernatants were collected, cleared of cell debris, and saved as Tatcontaining conditioned media from human primary astrocytes.

Western blotting. Cells were washed twice with ice-cold PBS and lyzed in RIPA buffer [50 mm Tris.HCl, pH 7.4, $150 \mathrm{~mm} \mathrm{NaCl,} \%$ Triton X-100, $1 \%$ sodium deoxycholate, $0.1 \%$ SDS, $2 \mathrm{~mm}$ PMSF, and $1 \times$ protease inhibitor mixture (Roche)] on ice for $20 \mathrm{~min}$ for whole-cell lysate preparation. Protein concentration was determined using a Bio-Rad DC protein assay kit (Bio-Rad). Cell lysates were electrophoretically separated by $10 \%$ SDS-polyacrylamide gel for Western blotting with appropriate primary antibodies: mouse monoclonal $\alpha$-NeuN (Millipore), goat polyclonal $\alpha$-doublecortin (DCX; Santa Cruz Biotechnologies), rabbit polyclonal $\alpha$-GFAP (DAKO), mouse monoclonal $\alpha$-Hes1 (Santa Cruz Biotechnologies), and mouse monoclonal $\alpha$ - $\beta$-actin (Sigma-Aldrich), followed by ECL detection and imaging using a Bio-Rad ChemicDoc imaging system.

Immunofluorescence staining for neurospheres. Neurospheres were washed with ice-cold PBS at room temperature and fixed with $4 \%$ paraformaldehyde for $30 \mathrm{~min}$, and followed by permeabilizing with $0.5 \%$ Triton X-100 in PBS for 30 min and blocking with PBS-BB (5\% BSA, 1\% nonfat milk and $0.3 \%$ Triton X-100 in PBS) for $1 \mathrm{~h}$. Then, neurospheres were incubated in mouse monoclonal $\alpha$-MAP-2 (1:200; Santa Cruz Biotechnologies) and rabbit polyclonal $\alpha$-glial fibrillary acidic protein $(\alpha$ GFAP; 1:200; DAKO) in PBS-BB at $4^{\circ} \mathrm{C}$ overnight, and goat anti-mouse Alexa fluor 555 (1:500; Life Technologies) and goat anti-rabbit Alexa fluor 488 (1:500, Life Technologies) in PBS-BB at room temperature for $1 \mathrm{~h}$. Nuclei were counterstained with $0.1 \mu \mathrm{g} / \mathrm{ml} \mathrm{4}$, 6-diamidino-2phenylindole (DAPI). Extensive washes with PBS were performed between each step. Omission of the primary antibody in parallel staining was included as a control to ensure no nonspecific staining. ImageJ software (NIH) was used to quantify the fluorescence intensity of the staining samples.

Floating staining for mouse brain tissues and quantification. Optimal cutting temperature (OCT) compound-embedded brains were sectioned (30 $\mu \mathrm{m}$ thick) throughout the rostrocaudal extent of the hippocampal dentate gyrus of the mouse brain using a cryostat (Leica). A one-in-six series of floating sections were washed in PBS three times, 5 min each time to remove cryobuffer and the OCT compound. Then the section was incubated in $0.2 \mathrm{~N} \mathrm{HCl}$ at room temperature for $1 \mathrm{~h}$, in $10 \mathrm{~mm}$ sodium borate for $10 \mathrm{~min}$, and in PBS-BB for $1 \mathrm{~h}$, then incubated with rat monoclonal $\alpha$-BrdU (1:100; Thermo Fisher Scientific) or mouse polyclonal $\alpha$-NeuN (1:100; Millipore) in PBS at $4^{\circ} \mathrm{C}$ overnight, and with goat anti-mouse Alexa fluor 555 (1:500; Life Technologies) and goat antirabbit Alexa fluor 488 (1:500; Life Technologies) in PBS-BB at room temperature for $1 \mathrm{~h}$. Nuclei were counterstained with $0.1 \mu \mathrm{g} / \mathrm{ml}$ DAPI. Extensive washes with PBS were performed between each step. Omission of the primary antibody in parallel staining was included as a control to ensure no nonspecific staining. The number of the GFP $+\mathrm{BrdU}+$ or
$\mathrm{NeuN}+\mathrm{BrdU}+$ cells in the brain was stereologically counted essentially as previously described (Gao and Chen, 2013).

$\beta$-Galactosidase and luciferase reporter gene assays. Cells were washed twice with ice-cold PBS, suspended with $200 \mu \mathrm{l} 1 \times$ reporter lysis buffer (Promega), and incubated at room temperature for $5 \mathrm{~min}$. The clear supernatant was collected by brief centrifugation. For $\beta$-galactosidase reporter gene assay, $10 \mu \mathrm{l}$ cell lysates were mixed with $3 \mu \mathrm{l}$ of $100 \times \mathrm{Mg}^{2+}$ solution $\left(0.1 \mathrm{M} \mathrm{MgCl}_{2}\right.$ and $4.5 \mathrm{M}$ mecaptoethanol, $66 \mu \mathrm{l}$ of $4 \mathrm{ng} / \mathrm{ml} o$-nitrophenyl-Dgalactopyranoside in $0.1 \mathrm{M}$ sodium phosphate, $\mathrm{pH} 7.5$, and $201 \mu \mathrm{l}$ of $0.1 \mathrm{M}$ sodium phosphate, $\mathrm{pH}$ 7.5. The mixture was incubated at $37^{\circ} \mathrm{C}$ for $30 \mathrm{~min}$. The optical density at $405 \mathrm{~nm}$ wavelength was determined using a Bio-Rad iMark microplate reader. The $\beta$-galactosidase activity was used to normalize the transfection variations among transfections for the subsequent luciferase reporter gene assay, which was conducted using a luciferase assay system (Promega). The luciferase activity was quantitated using an Opticomp Luminometer (MGM Instruments).

Data analysis. All experiment data were analyzed by one-way ANOVA and two-tailed Student's $t$ test. A $p$ value $<0.05$ was considered to be statistically significant and marked with an asterisk.

\section{Results}

\section{Impaired neurogenesis in the dentate gyrus of the hippocampus of Tat-expressing mice}

To determine effects of HIV Tat expression on neurogenesis, we took advantage of the iTat mice and the nestin-GFP mice. When given Dox, iTat mice express a physiological level of Tat protein in the CNS and induce a variety of neuropathological and neurobehavioral changes reminiscent of HIV/neuroAIDS (Kim et al., 2003). GFP expression in nestin-GFP mice allows accurate and sensitive determination of nestin + (namely, GFP+) NPCs (Mignone et al., 2004). Nestin-GFP mice were crossbred with iTat mice to generate nestin-GFP/iTat mice. Both nestin-GFP mice and nestin-GFP/iTat mice were given Dox. Tat expression in those mice were confirmed as previously described (Kim et al., 2003; Zou et al., 2010; Fan et al., 2011, 2015). Compared with nestin-GFP mice, nestin-GFP/iTat mice had considerably fewer $\mathrm{GFP}+\mathrm{NPCs}$ in the dentate gyrus of the hippocampus (Fig. $1 A, B$, GFP column, $D$ ). Similarly, the number of cells positive for DCX, a marker for immature neurons in the early neurogenesis (Brown et al., 2003; Mishra et al., 2010), in the dentate gyrus of the hippocampus of nestin-GFP/iTat mice was considerably lower than the comparable number in nestin-GFP mice (Fig. 1A, DCX column, E). In addition, the number of cells positive for GFAP, a marker for astrocytes (Eng and Ghirnikar, 1994), in the dentate gyrus of the hippocampus of nestin-GFP/iTat mice was considerably higher than the comparable number in nestin-GFP mice (Fig. $1 B$, GFAP column, $F$ ).

Next, nestin-GFP and nestin-GFP/iTat mice were given Dox as well as BrdU for a shorter period of time. NPC proliferation $(\mathrm{GFP}+\mathrm{BrdU}+$ cells) in both mice was determined (Fig. 2A). Compared with nestin-GFP mice, nestin-GFP/iTat mice have significantly fewer GFP + BrdU + cells in the dentate gyrus of the hippocampus (Fig. 2B). Last, after WT and iTat mice were given Dox as well as BrdU for a longer period of time, the number of newly produced mature neurons $(\mathrm{NeuN}+\mathrm{BrdU}+$ cells $)$ in both mice was determined. Compared with WT mice, iTat mice have significantly fewer $\mathrm{NeuN}+\mathrm{BrdU}+$ cells in the dentate gyrus of the hippocampus (Fig. 2B). No GFAP + BrdU+ cells were detected in the dentate gyrus of the hippocampus of both WT and iTat mice (data not shown), likely due to more rapid astrocyte proliferation and loss of BrdU signal in the cells. These results provide the first evidence to support the in vivo association of Tat expression with fewer NPCs and immature neurons, less NPC proliferation, and fewer NPC-derived mature neurons in the dentate gyrus of the hippocampus. 
A

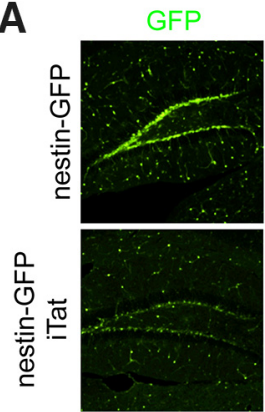

B GFP

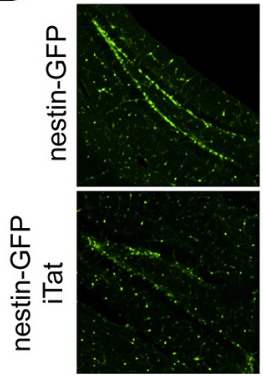

$\mathrm{DCX}$

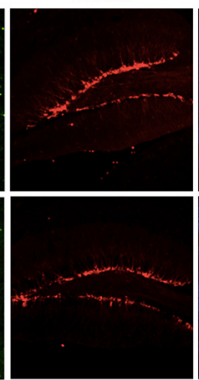

GFAP

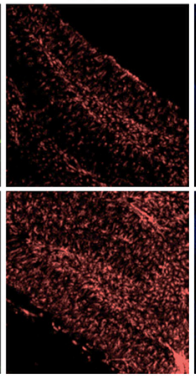

DAPI

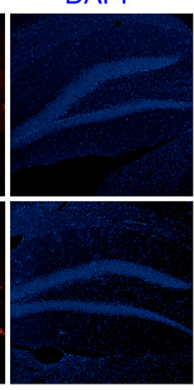

DAPI

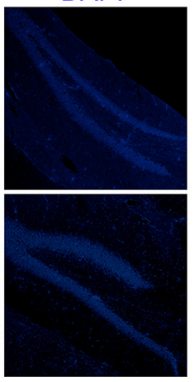

C

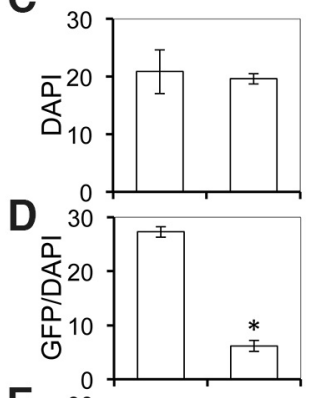

E

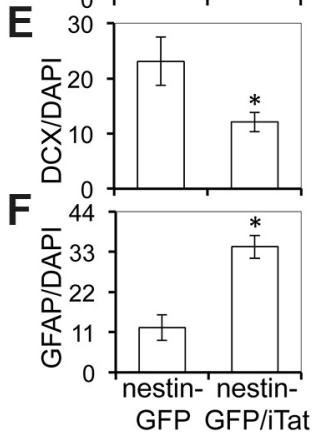

Figure 1. Fewer NPC $(G F P+)$ and immature neurons $(D C X+)$ in the dentate gyrus of the hippocampus of Tatexpressing mouse brain. Four-week-old nestin-GFP mice and nestin-GFP/iTat mice were intraperitoneally injected with Dox for $7 \mathrm{~d}$. $\boldsymbol{A}, \boldsymbol{B}$, The brains were collected, sectioned, and stained with anti-DCX antibody $(\boldsymbol{A})$ or anti-GFAP antibody $(\boldsymbol{B})$, followed by donkey anti-goat Alexa fluor 555 . The brain sections were then counterstained with DAPI for nuclei, and the micrographs were taken from comparable regions of the dentate gyrus of the hippocampus of the brains ( 3 mice in each group). The images were representative of all the stained brain sections in each group. $\mathbf{C}-\boldsymbol{F}$, ImageJ software (NIH) was used to quantify the relative immunofluorescence intensity of each staining. The surrounding background was subtracted. DAPI $(\boldsymbol{C})$ was used as a reference to compare the signal intensity of GFP $(\boldsymbol{D}), \mathrm{DCX}(\boldsymbol{E})$, or GFAP $(\boldsymbol{F})$. The data were mean \pm SD of three brains in each group.

A GFPBrdU

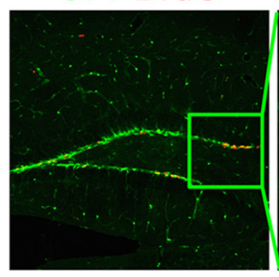

C NeuNBrdUDAPI
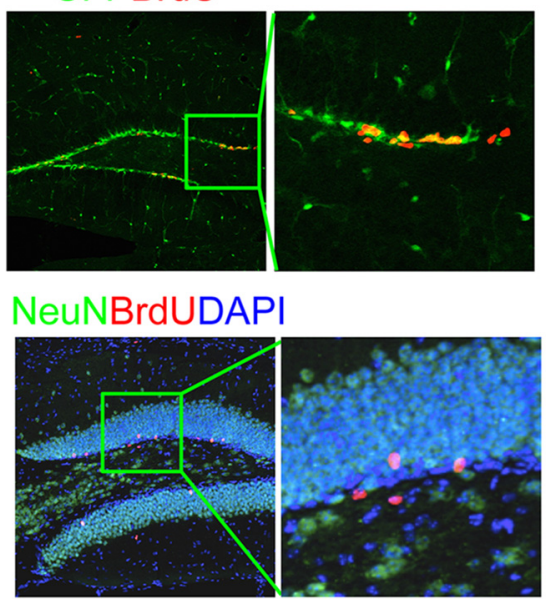

B
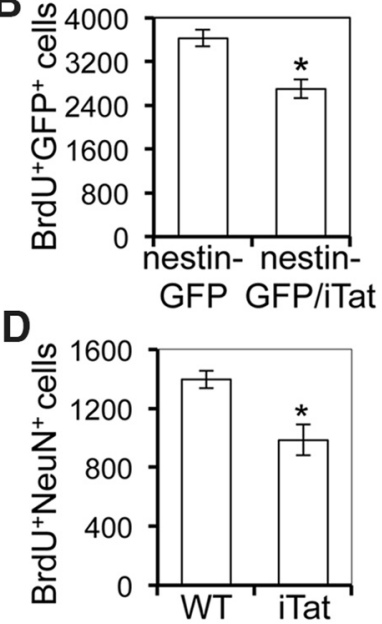

Figure 2. Decreased NPC proliferation (GFP + BrdU +) and fewer mature neurons (NeuN + BrdU + ) in the dentate gyrus of the hippocampus of Tat-expressing mouse brain. $\boldsymbol{A}, \boldsymbol{B}$, Four-week-old nestin-GFP mice and nestin-GFP/iTat mice were intraperitoneally injected with Dox for $4 \mathrm{~d}$ and then Dox plus BrdU for $3 \mathrm{~d}$. Mouse brains were collected, sectioned, and stained with anti-BrdU antibody, followed by donkey anti-rat Alexa fluor 555 . The dentate gyrus of the hippocampus of the brains from each group was photographed $(\boldsymbol{A}$, left). Inset $(\boldsymbol{A}$, right) shows portion of image under high magnification. $\mathrm{GFP}+\mathrm{BrdU}+$ cells were stereologically counted $(\boldsymbol{B})$. The data were mean \pm SD. of three brains in each group. $\boldsymbol{C}, \boldsymbol{D}$, Eight-week-old WT and iTat mice were intraperitoneally injected with Dox for $4 \mathrm{~d}$, Dox plus BrdU for $3 \mathrm{~d}$, and BrdU alone for $4 \mathrm{~d}$. Mouse brains were collected $25 \mathrm{~d}$ after the final injection, and stained with anti-BrdU and anti-NeuN antibody, followed by donkey anti-rat Alexa fluor 555 and goat anti-mouse Alexa fluor 488. The dentate gyrus of the hippocampus regions of the brains for each staining were photographed ( $\boldsymbol{C}$, left). Inset ( $\boldsymbol{C}$, right) shows portion of image under high magnification. NeuN + BrdU + cells were stereologically counted in the dentate gyrus of the hippocampus of iTat-induced and WT-induced mouse brain $(\boldsymbol{D})$. The data were mean \pm SD. of three brains in each group.

HIV Tat impaired NPC proliferation, migration, and differentiation in vitro To further determine the relationship between Tat expression and neurogenesis, NPCs were isolated from the mouse brain and assessed for their proliferation. Conditioned media from Tat-expressing astrocytes were first used as a source of biologically active Tat protein. When conditioned media from Dox-induced mouse primary astrocytes were used (Fig. $3 A$ ), iTat conditioned medium gave rise to significantly smaller NPC-derived neurospheres than WT conditioned medium (Fig. 3B). Next, NPC migration was assessed in the presence of conditioned media or recombinant Tat protein. Considering the finding that HIV-1 Tat inhibits cell proliferation (Viscidi et al., 1989; Prakash et al., 2001; Zhou and He, 2004), which may not allow us to distinguish Tat-impaired NPC migration from Tat-induced inhibition of NPC proliferation, we treated neurospheres first with mitomycin $\mathrm{C}$ to inhibit neurosphere proliferation (Shikatani et al., 2012) and then with Tat-containing conditioned media, and determined Tat effects on the neurosphere migration. Conditioned medium from Dox-induced iTat mouse primary astrocytes showed a significantly shorter NPC migration distance than that from Doxinduced WT mouse primary astrocytes (Fig. $3 C, D)$. Last, NPC differentiation was assessed in the presence of conditioned media or recombinant Tat protein. Compared with the mock and WT controls, iTat conditioned medium decreased DCX and NeuN expression and increased GFAP expression in NPC-derived neurospheres over time by Western blotting (Fig. 3E) and decreased MAP-2 expression and increased GFAP expression in neurospheres by immunofluorescence staining (Fig. $3 F$ ).

Similar results on NPC proliferation were obtained with conditioned media from Tat-transfected human primary astrocytes (Fig. 4A,B). Given the possible presence of other unknown soluble factors in Tat-containing conditioned media, NPC proliferation was directly assessed using recombinant Tat protein. More Tat protein was associated with the formation of significantly smaller NPC-derived neurospheres (Fig. 4C,D). A significantly shorter NPC migration distance was also noted when conditioned medium from Tat-transfected human primary astrocytes (Fig. $5 A$ ) or recombinant Tat protein was used (Fig. 5B). Recombinant Tat protein also gave rise to similar results on NPC differentiation (Fig. $6 A, B)$. Furthermore, conditioned medium from Tat-expressing human primary astrocytes were immunodepleted of Tat and as- 
A

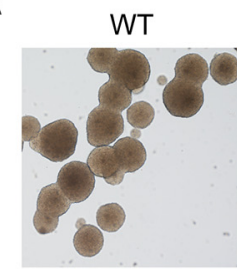

B

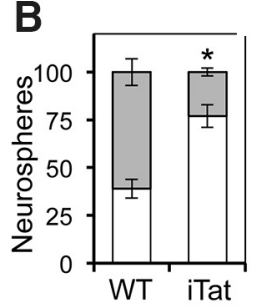

C

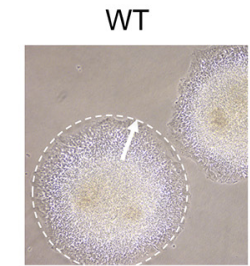

iTat

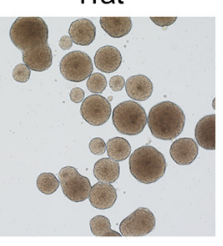

D

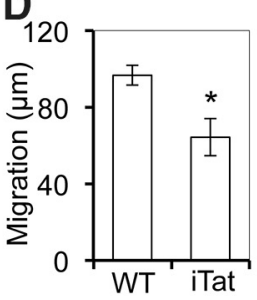

iTat

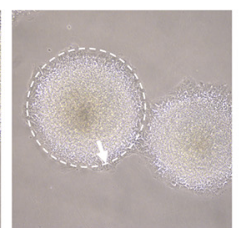

E

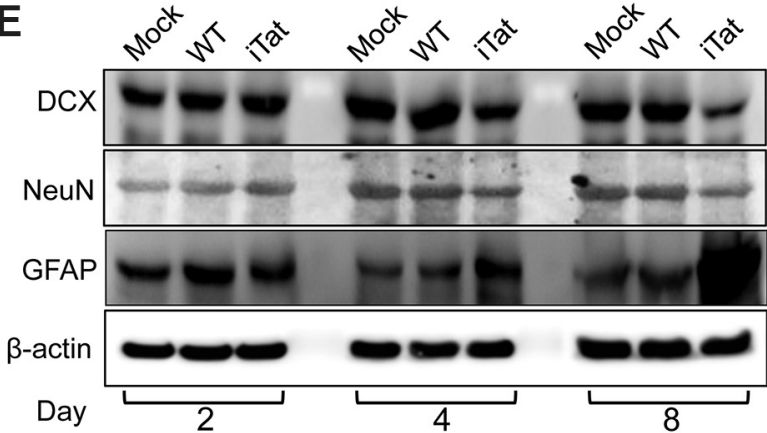

$F$ MAP-2 GFAP

MAP-2GFAPDAPI

WT
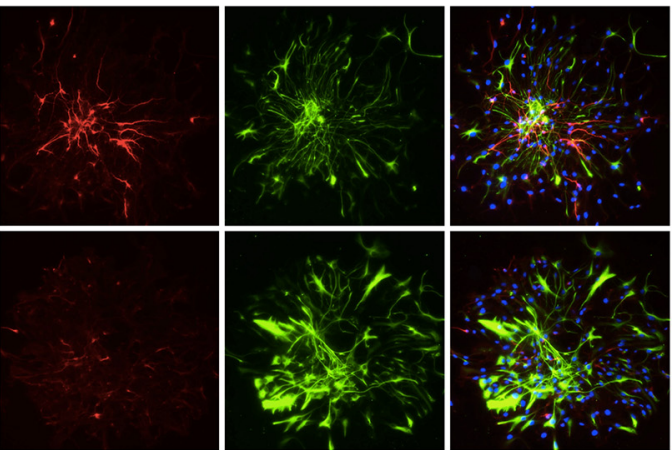

Figure 3. Impaired NPC proliferation, migration, and differentiation by Tat-containing conditioned media. Neurospheres derived from mouse NPCs at the seventh day of cultures were trypsinized to obtain single cells. $\boldsymbol{A}, \boldsymbol{B}$, The single cells were cultured in a nontreated 12-well plate in the presence of conditioned medium from Dox-induced WT and iTat mouse primary astrocytes for $7 \mathrm{~d}(\boldsymbol{A})$, followed by quantitation of the sizes of neurospheres ( $\boldsymbol{B}$, open bars: diameter of neurospheres, $<60 \mu \mathrm{m}$; closed bars: diameter of neurospheres, $>60 \mu \mathrm{m}$ ). $C, D$, Neurospheres derived from mouse NPCs at the seventh day of cultures were cultured in a poly-lysine-coated 24-well plate in the presence of mitomycin C for $2 \mathrm{~h}$ and then conditioned medium from Dox-induced WT and iTat mouse primary astrocytes for $16 \mathrm{~h}$, followed by quantitation of the migration distance from the center of 30 randomly selected neurospheres. $E, F$, The single cells were cultured in a poly-lysine-coated 24-well plate in the presence of conditioned medium from Dox-induced WT and iTat mouse primary astrocytes for 2, 4, and $8 \mathrm{~d}$, followed by Western blotting $(\boldsymbol{E})$ and immunofluorescence staining $(\boldsymbol{F}$; at day 8). The single cells cultured in the NPC medium were included as a mock control $(\boldsymbol{E})$. The images/blots were representative of all the neurospheres in each sample. The data were mean \pm SD of triplicates in each group and representative of three independent experiments.

A

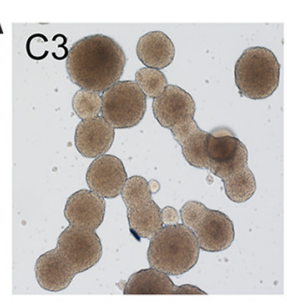

$\mathbf{C}$

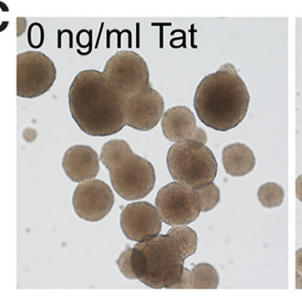

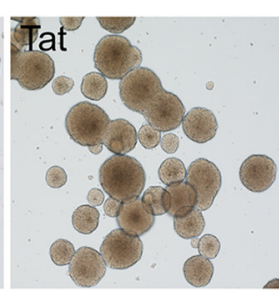

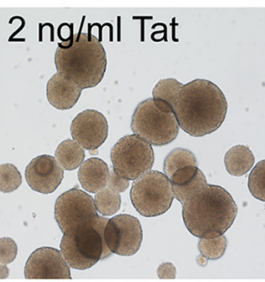

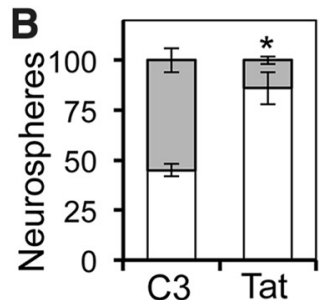

C3 Tat

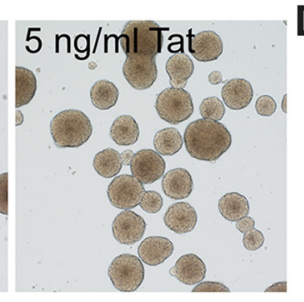

Figure 4. Impaired NPC proliferation by Tat-containing conditioned media and recombinant Tat protein. Neurospheres derived from mouse NPCs at the seventh day of cultures were trypsinized to obtain single cells. $\boldsymbol{A}-\boldsymbol{D}$, Those single cells were cultured in the presence of conditioned media from Tat-transfected and (3-transfected human primary astrocytes $(\boldsymbol{A})$, or recombinant Tat protein (C) for $7 \mathrm{~d}$, followed by quantitation of the sizes of neurospheres ( $\boldsymbol{B}, \boldsymbol{D}$, open bars: diameter of neurospheres, $<60 \mu \mathrm{m}$; closed bars: diameter of neurospheres, $>60 \mu \mathrm{m})$. The images were representative of all the neurospheres in each sample. The data were mean \pm SD of triplicates in each group and representative of three independent experiments.

sessed for its effects on NPC differentiation. Compared with the isotype-matched IgG control, Tat depletion restored normal DCX, NeuN, and GFAP expression in the neurospheres (Fig. 7A). Heat inactivation of recombinant Tat protein showed similar results (Fig. 7B).

To ensure that the viability of the neurospheres with different treatments were comparable, the LDH cytotoxicity assay was per- formed with neurospheres treated with Tat-containing conditioned media or recombinant Tat protein. Compared with the controls, no significant cytotoxicity in neurospheres was detected in neurospheres treated with Tat-containing conditioned media or recombinant Tat protein (data not shown). In addition, to address the physiological relevance of the findings above, the TZM-bl-based reporter gene assay was performed to determine 
A
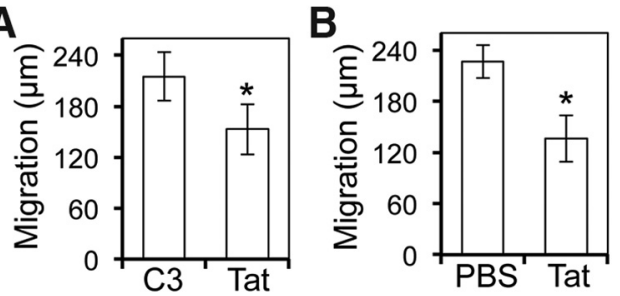

Figure 5. Impaired NPC migration by Tat-containing conditioned media and recombinant Tat protein. Neurospheres derived from mouse NPCs at the seventh day of cultures were trypsinized to obtain single cells. $\boldsymbol{A}, \boldsymbol{B}$, The single cells were cultured in the presence of conditioned media from Tat-transfected and (3-transfected human primary astrocytes $(\boldsymbol{A})$ or recombinant Tat protein $(\boldsymbol{B})$ for $48 \mathrm{~h}$, followed by quantitation of the migration distance from the center of 20 randomly selected neurospheres. The data were mean \pm SD of triplicates in each group and representative of three independent experiments.

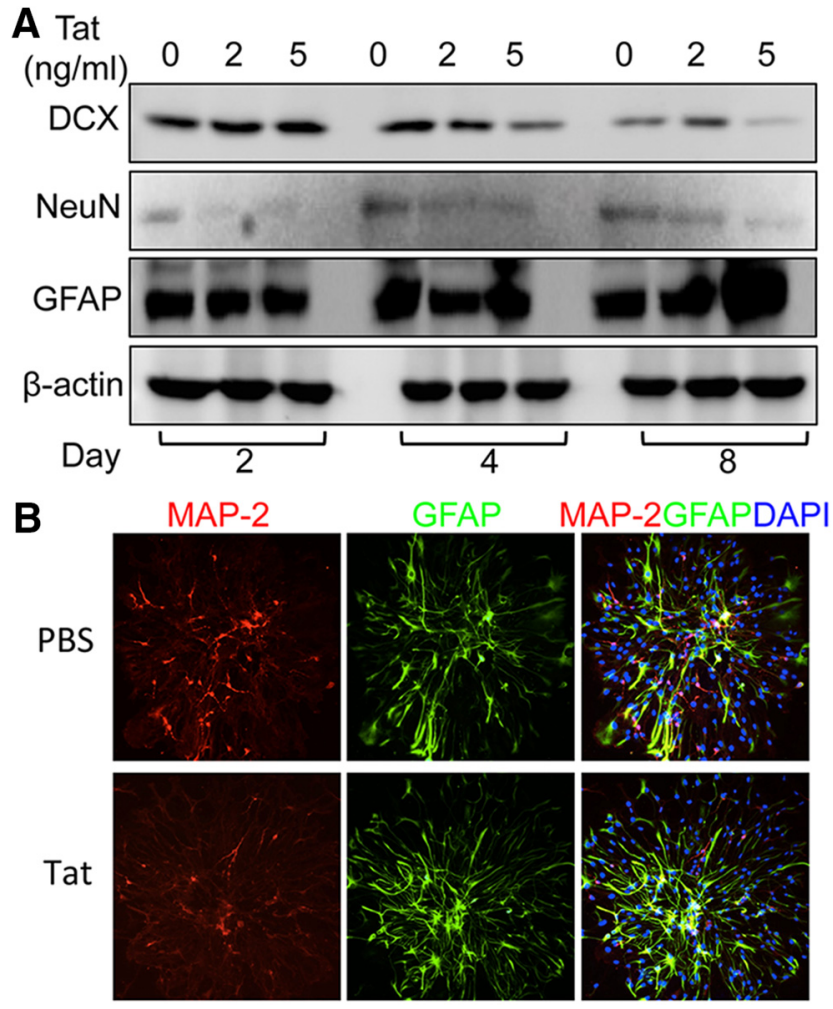

Figure 6. Impaired NPC differentiation by recombinant Tat protein. Neurospheres derived from mouse NPCs at the seventh day of cultures were trypsinized to obtain single cells. $\boldsymbol{A}, \boldsymbol{B}$, Those single cells were cultured in the presence of 0,2 , and $5 \mathrm{ng} / \mathrm{ml}$ recombinant Tat protein for 2,4 , and $8 \mathrm{~d}$ and harvested for Western blotting $(\boldsymbol{A})$ or stained for MAP-2, GFAP antibodies, followed by goat anti-mouse Alexa fluor 555 and goat anti-rabbit Alexa fluor 488 and DAPI (B; only for neurospheres at day 8). The blots/images were representative of all the stained neurospheres in each group and were representative of three independent experiments.

the level of Tat protein in the Tat-containing conditioned media. The level of Tat protein in the Tat-containing conditioned media was found to be in the range of $1-5 \mathrm{ng} / \mathrm{ml}$ (data not shown), which is close to the reported Tat concentration in the brains of HIV-infected individuals (Westendorp et al., 1995; Xiao et al., 2000). Together, these results support the notion that Tat directly alters NPC proliferation, migration, and differentiation.

\section{Activation of Notch signaling by HIV Tat}

Notch signaling (activation) is elicited by binding of Notch ligands to the extracellular domain of the Notch receptors, followed by activation of downstream genes, such as transcription factor hairy and
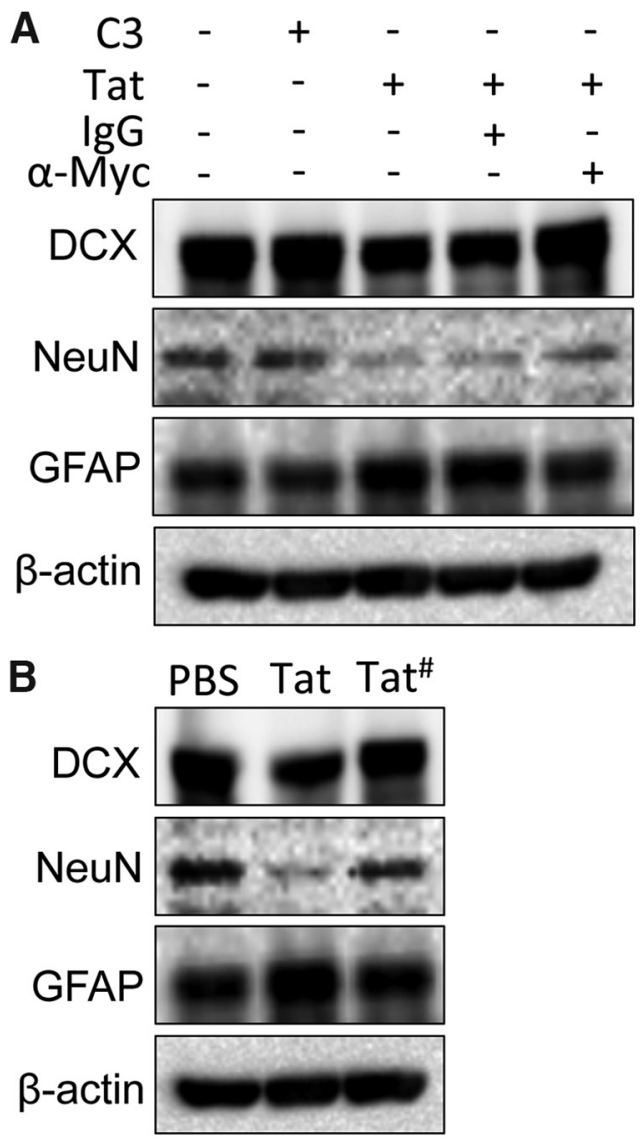

Figure 7. Rescue of normal NeuN, DCX, and GFAP expression in neurospheres by Tat immunodepletion and heat inactivation. Neurospheres derived from mouse NPCs at the seventh day of cultures were trypsinized to obtain single cells. $\boldsymbol{A}, \boldsymbol{B}$, The single cells were cultured in the presence of conditioned media and Tat-immunodepleted condition media from Tat-transfected or (3-transfected human primary astrocytes for $8 \mathrm{~d}$ and harvested for Western blotting $(A)$, or in the presence of $5 \mathrm{ng} / \mathrm{ml} \mathrm{recombinant} \mathrm{Tat} \mathrm{or} \mathrm{heat-denatured} \mathrm{recombinant} \mathrm{Tat} \mathrm{(Tat}{ }^{\#}$ ) for $8 \mathrm{~d}$ and harvested for Western blotting $(\boldsymbol{B})$. Isotype-matched $\lg \mathrm{G}$ was used as an immunodepletion control $(\boldsymbol{A})$. PBS was included as a solvent control $(\boldsymbol{B})$. The data were representative of three independent experiments.

enhancer of split-1 (Hes1; Kageyama and Ohtsuka, 1999). One or more epidermal growth factor (EGF)-like motifs are presented in the extracellular domain of all the Notch isoforms and their respective ligands, and are directly involved in Notch/ligand interactions (Chillakuri et al., 2012). In our previous study, we identified several Tatbinding proteins (Liu et al., 2002; data not shown), the majority of which possess $\geq 1$ EGF-like motifs. HIV-1 Tat has indeed been shown to bind to the EGF-like motifs within the extracellular domain of the Notch receptor (Shoham et al., 2003a). These findings led us to propose that Tat might function as a Notch ligand and regulate neurogenesis through binding to the Notch receptor and subsequently activating Notch signaling. To test this hypothesis, Notch downstream gene Hes1 promoter-driven luciferase (Luc) reporter was transfected with an increasing amount of Tat. Then Luc activity was determined and used as an indirect indictor of Notch signaling activation. Significant levels of the Luc activity were detected in cells transfected with Hes1-Luc and 0.1 and $0.2 \mu \mathrm{g}$ of Tat expression plasmids (Fig. 8A). Next, Hes1 protein expression was determined in NPC-derived neurospheres using conditioned media from Dox-induced WT and iTat mouse primary astrocytes. Compared with the mock and WT controls, iTat conditioned medium showed increased Hes1 protein expression in NPC-derived neurospheres (Fig. 8B). Recombinant Tat treatment also increased Hes1 
A
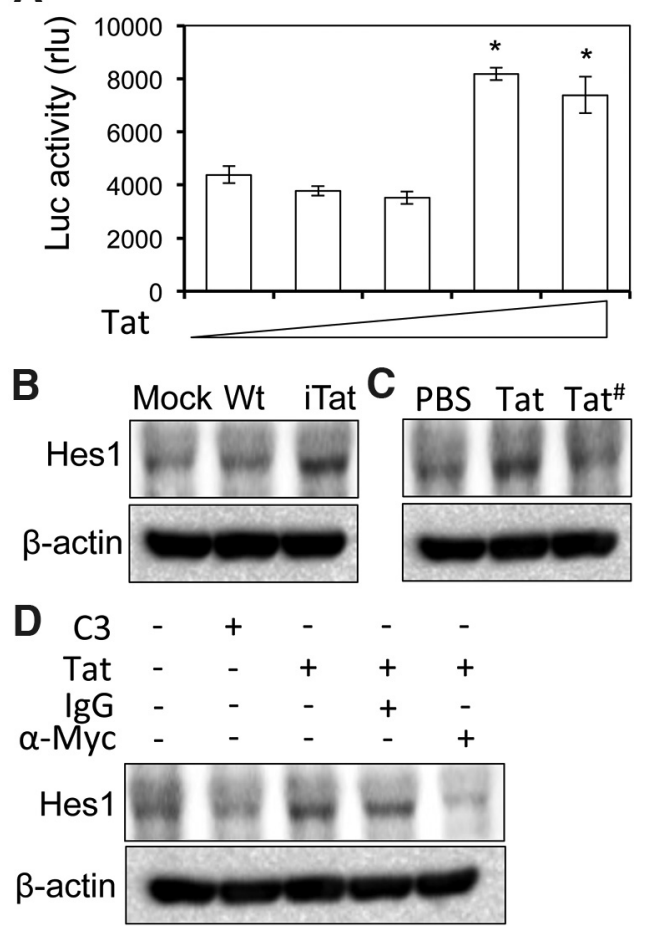

Figure 8. Transactivation of Hes 1 expression by HIV-1 Tat. $\boldsymbol{A}$, Human primary astrocytes were transfected with $H$ es 1 promoter-driven luciferase reporter gene with $0,0.01,005,0.1$, and $0.2 \mu \mathrm{g}$ of Tat expression plasmid. Cells were harvested $72 \mathrm{~h}$ after transfection for luciferase reporter gene assay. C 3 was included to equalize the total amount of transfected DNA. pCMV$\beta$-gal was used to normalize the transfection efficiency variations among all transfections. Statistical analysis was performed using (3-transfected cells (open bar) as the reference. The data were mean $\pm S D$ of triplicates and representative of three independent experiments. $B-D$, Neurospheres derived from mouse NPCs at the seventh day of cultures were trypsinized to obtain single cells. The single cells were cultured in the presence of conditioned medium from Dox-induced WT and iTat mouse primary astrocytes $(\boldsymbol{B})$, recombinant Tat and heat-denatured recombinant Tat $\left(\boldsymbol{C}\right.$, Tat $\left.{ }^{\#}\right)$, or conditioned media and Tat-immunodepleted condition media from Tat-transfected or C3-transfected human primary astrocytes (D) for $8 \mathrm{~d}$ and harvested for Western blotting. The single cells cultured in the NPC medium were included as a mock control $(\boldsymbol{B})$. PBS was included as a solvent control (C). Isotype-matched lgG was used as an immunodepletion control (D). $\beta$-Actin was included as an equal loading control ( $\boldsymbol{B}-\boldsymbol{D})$. The data were representative of three independent experiments.

protein expression, while heat-inactivated Tat did not show much change (Fig. 8C). Furthermore, increased Hes1 protein expression by Tat-expressing conditioned medium was abrogated by immunodepletion of Tat from the conditioned medium (Fig. 8D). These results demonstrated that Tat-containing conditioned media or recombinant Tat protein were capable of inducing Hes1 expression at both mRNA and protein levels.

HIV Tat protein has a cysteine-rich domain adjacent to the $\mathrm{N}$ terminus of the protein. This domain is important for Tat transactivation activity on the HIV LTR promoter and binding to other cellular cofactors (Shoham et al., 2003a; Ranga et al., 2004). An early study has shown that cysteines within the cysteine-rich domain of the Tat protein from the caprine arthritis encephalitis virus, a retrovirus closely related to HIV, are directly involved in Tat interaction with the EGF-like motifs of the Notch receptor (Shoham et al., 2003b). Thus, we next determined the specificity of the relationship between Hesl activation and Tat/Notch interaction using a set of Tat mutants derived from subtype C HIV strains WT Tat (Tat ${ }^{\mathrm{cs}}$; Tat with cysteine at amino acid residue 30 and serine at amino acid residue 31 ) and mutants Tat $^{\text {cc }}$ (the WT cysteine-rich domain of subtype C Tat replaced with that of subtype B Tat, in which Tat with cysteine at both amino acid residue 30 and amino acid residue 31), and Tat $^{\text {sc }}$ (Tat with serine at amino acid residue 30 and cysteine at amino acid residue 31; Ranga et al., 2004). First, Tat ${ }^{\mathrm{cs}}$, Tat ${ }^{\mathrm{cc}}$, and $\mathrm{Tat}^{\mathrm{sc}}$ were assessed for their activity on Hes1-Luc reporter gene expression. Compared with the $\mathrm{C} 3$ control, Tat ${ }^{\mathrm{cs}}$ and Tat ${ }^{\mathrm{cc}}$ activated Hes1-Luc expression, albeit at a lower level than Tat derived from NL4-3 subtype B HIV strain (Fig. 9A). In contrast, Tat ${ }^{\text {sc }}$ showed little effect on Hes1-Luc expression. Despite the findings that Tat is secreted outside Tat-expressing cells to function as a ligand to interact with the extracellular domain of the Notch receptor, it was imperative to ascertain that extracellular Tat could indeed transactivate Hes1-Luc expression. Thus, conditioned media from Tat-transfected human primary astrocytes were added to cells transfected with the Hes1-Luc reporter gene. Cells transfected with HIV-1 LTR-Luc were included to monitor Tat biological activity. Similarly to direct transfection (Fig. 9A), conditioned media from Tat-expressing, Tat ${ }^{\mathrm{cs}}$-expressing, and $\mathrm{Tat}^{\mathrm{cc}}$-expressing cells, but not those from Tat ${ }^{\mathrm{sc}}$-expressing cells, transactivated Hes1-Luc expression (Fig. 9B, open bars). As shown above, conditioned media from Tat-expressing, Tat ${ }^{\mathrm{cs}}$-expressing, and $\mathrm{Tat}^{\mathrm{cc}}{ }^{\mathrm{c}}$-expressing cells, but not those from Tat ${ }^{\text {sc }}$-expressing cells, transactivated HIV LTR-Luc expression (Fig. $9 B$, closed bars). In addition, the same conditioned media were also added to NPC-derived neurospheres and assessed for their effects on NPC differentiation. Compared with the C3 control, conditioned media from $\mathrm{Tat}^{\mathrm{cs}}$-expressing and $\mathrm{Tat}^{\mathrm{cc}}$-expressing cells increased Hes1 protein expression and GFAP expression in the neurospheres and decreased DCX and NeuN expression in neurospheres, but conditioned media from $\mathrm{Tat}^{\mathrm{sc}}$-expressing cells showed little change (Fig. $9 C)$. Together, these results indicate that Tat functions as a Notch ligand and likely regulates neurogenesis through binding of the Tat cysteine-rich domain to the EGF-like motifs within the extracellular domain of the Notch receptor and activation of the Notch signaling pathway.

\section{Inhibition of Notch signaling significantly alleviated Tat-impaired NPC differentiation in vitro and neurogenesis in vivo}

To determine the significance of Tat/Notch signaling in Tatimpaired NPC differentiation in vitro, we took advantage of two well characterized inhibitors of Notch signaling. One is DAPT, which is a $\gamma$-secretase inhibitor and an indirect inhibitor of Notch, a $\gamma$-secretase substrate (Netzer et al., 2010). The other is delta-like 1 homolog (DLK1), which is one of the noncanonical Notch ligands and acts as a competitive ligand to inhibit Notch signaling (Falix et al., 2012; Rodríguez et al., 2012). Jaaged-1 was included as the constitutive Notch ligand and a positive control for Notch signaling ( $\mathrm{Ba}$ et al., 2012). DAPT, DLK1, Jagged-1, or DLK1 plus Jagged-1 were included in the NPC-derived neurosphere cultures treated with conditioned media from Dox-induced WT and iTat mouse primary astrocytes. Compared with the respective mock control, DAPT or DLK1 only had a subtle effect on Hes1, DCX, NeuN, and GFAP expression in neurospheres treated with WT conditioned medium, but significantly decreased Hes 1 and GFAP expression and increased DCX and NeuN expression in neurospheres treated with iTat conditioned medium (Fig. 10A). Jagged-1 increased Hes1 and GFAP expression and decreased DCX and NeuN expression in neurospheres in both WT and iTat conditioned media, while DLK1 plus Jagged-1 abrogated the changes. Compared with the WT control, iTat conditioned medium increased Hes 1 and GFAP expression in the neurospheres and decreased DCX and NeuN expression in the neurospheres (Fig. 10A). Next, Notch signaling inhibitor DAPT was assessed for its effects on Tat-impaired neurogenesis using the iTat mice. DAPT was given to mice along with Dox and BrdU. Newly 

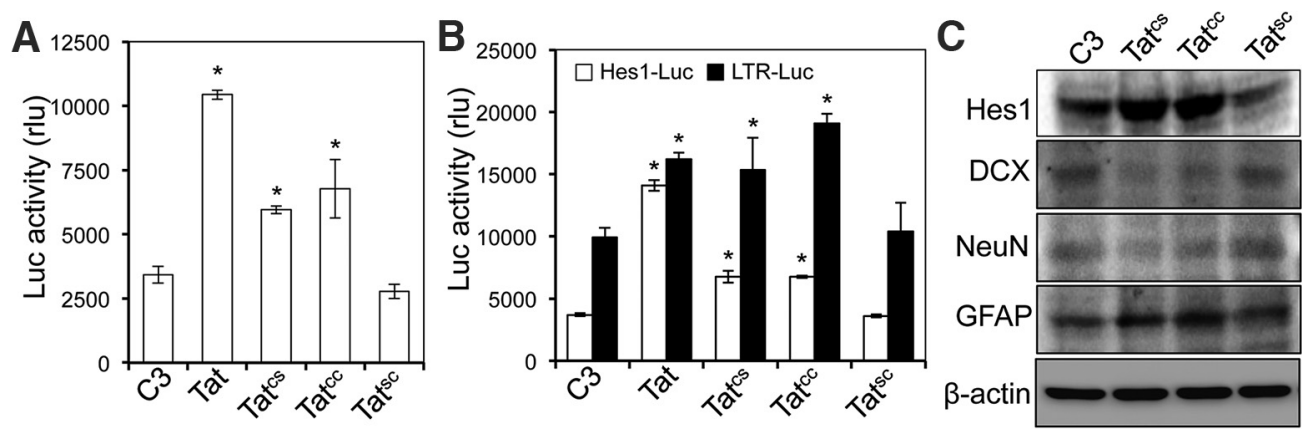

Figure 9. Requirement of cysteine at amino acid residue 30 for Tat-mediated Hes 1 transactivation. $A$, Human primary astrocytes were transfected with Hes 1 promoter-driven luciferase reporter gene with pTat.Myc, $\mathrm{pC}-\mathrm{Tat}^{\mathrm{CS}}, \mathrm{pC}-\mathrm{Tat}{ }^{\mathrm{CC}}$, or $\mathrm{pC}-\mathrm{Tat}^{\mathrm{SC}}$. Cells were harvested $72 \mathrm{~h}$ after transfection for the luciferase reporter gene assay. $\boldsymbol{B}$, Human primary astrocytes were transfected with $\mathrm{pTat}$.Myc, $\mathrm{pC}-\mathrm{Tat}^{\mathrm{CS}}, \mathrm{pC}$-Tat ${ }^{\mathrm{CC}}$, or pC-Tat ${ }^{\mathrm{SC}}$. Supernatants were collected $72 \mathrm{~h}$ after transfection and used to treat pHes1-Luc-transfected human primary astrocytes (B, open bars) or pLTR-Luc-transfected $293 \mathrm{~T}$ cells ( $\boldsymbol{B}$, closed bars). Cells were harvested for the luciferase activity assay $24 \mathrm{~h}$ after treatment. C3 was included to equalize the transfected DNA. pCMV- $\beta$-gal was included to normalize the transfection efficiency variations among all transfections. Statistical analysis was performed using (3-transfected cells as the reference. The data were mean \pm SD of triplicates and representative of three independent experiments. $\boldsymbol{C}$, The same supernatants were added on the single cells derived from neurospheres formed on the seventh day. After culturing for $8 \mathrm{~d}$, neurospheres were harvested for Western blotting. $\beta$-Actin was included as an equal loading control. The blots were representative of three independent experiments.
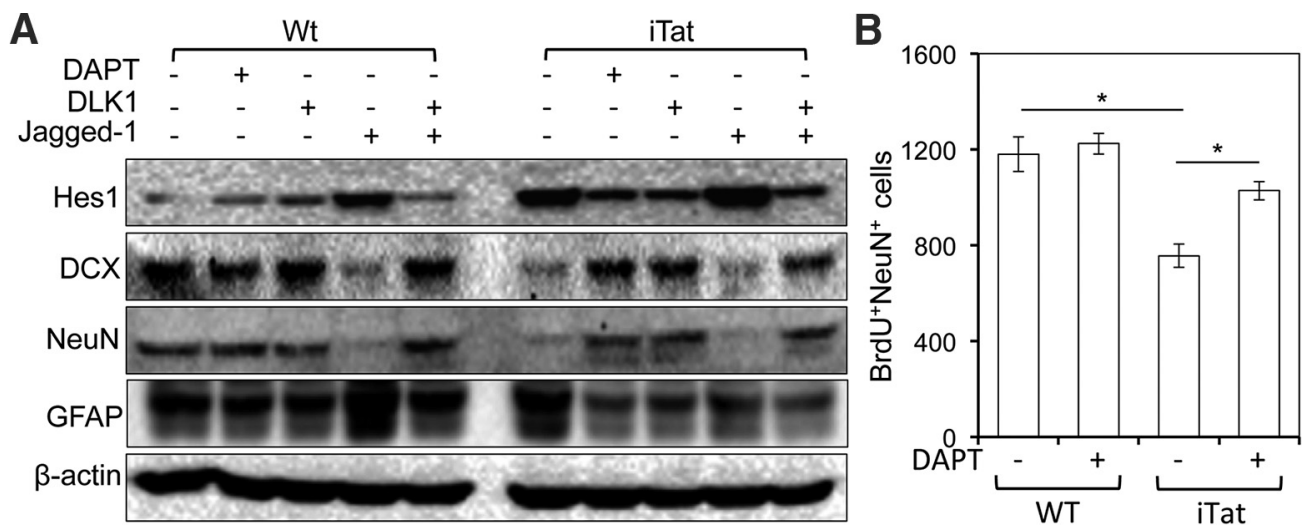

Figure 10. Inhibition of Notch signaling and rescue of impaired neurogenesis by Tat. $A$, Neurospheres derived from mouse NPCs at the seventh day of cultures were trypsinized to obtain single cells. The single cells were cultured in the presence of conditioned media from Dox-induced WT and iTat mouse primary astrocytes and Notch inhibitors DAPT (5 $\mu \mathrm{g} / \mathrm{ml})$ and DLK1 ( $500 \mathrm{ng} / \mathrm{ml})$, Notch activator Jagged-1 (100 ng/ml), or DLK1 plus Jagged-1 for $8 \mathrm{~d}$ and harvested for Western blotting. The blots were representative of three independent experiments. B, Eight-week-old WT and iTat mice were intraperitoneally injected with Dox and DAPT for $4 \mathrm{~d}$; with Dox, BrdU, and DAPT for $3 \mathrm{~d}$; and with BrdU alone for $4 \mathrm{~d}$. Mouse brains were collected $25 \mathrm{~d}$ after the final injection, and stained with anti-BrdU and anti-NeuN antibody antibodies, followed by donkey anti-rat Alexa fluor 555 and goat anti-mouse Alexa fluor 488 . NeuN + BrdU + cells were stereologically counted in the dentate gyrus of the hippocampus of iTat-induced and WT-induced mouse brain. The data were mean \pm SD. of three brains in each group.

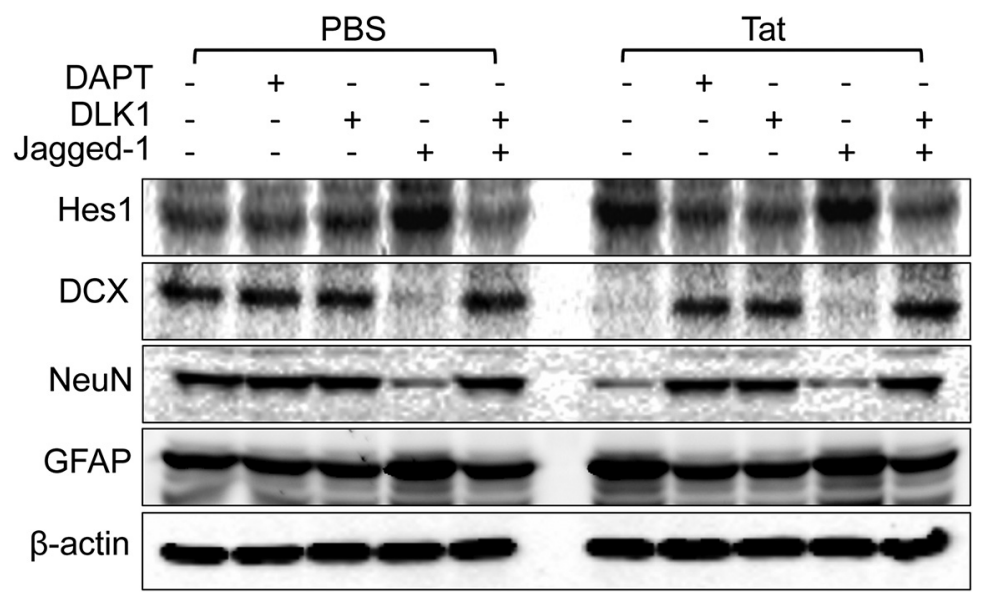

Figure 11. Inhibition of Notch signaling and rescue of normal NeuN, DCX, and GFAP expression in neurospheres altered by recombinant Tat. Neurospheres derived from mouse NPCs at the seventh day of cultures were trypsinized to obtain single cells. The single cells were cultured in the presence of $5 \mathrm{ng} / \mathrm{ml} \mathrm{recombinant} \mathrm{Tat} \mathrm{protein} \mathrm{and} \mathrm{Notch} \mathrm{inhibitors} \mathrm{DAPT} \mathrm{(} 5 \mu \mathrm{g} / \mathrm{ml}$ ) and DLK1 (500 $\mathrm{ng} / \mathrm{ml})$, Notch activator Jagged-1 (100 ng/ml), or DLK1 plus Jagged-1 for $8 \mathrm{~d}$ and harvested for Western blotting. PBS was used as the solvent control. The blots were representative of three independent experiments. produced neurons, namely BrdU $+\mathrm{NeuN}+$ cells, were determined $25 \mathrm{~d}$ after the final injection. Compared with the respective solvent control, DAPT had no effects on the number of BrdU+NeuN + cells in the dentate gyrus of the hippocampus of WT mice, but significantly increased the number of $\mathrm{BrdU}+\mathrm{NeuN}+$ cells in the dentate gyrus of the hippocampus of iTat mice (Fig. 10B). Those inhibitors exhibited similar effects on Hes1, DCX, NeuN, and GFAP expression in neurospheres treated with recombinant Tat protein (Fig. 11). These results provide further evidence to support the direct involvement of Tat interaction with Notch signaling in Tat-impaired neurogenesis.

\section{Discussion}

In the study, we aimed to determine Tat effects on neurogenesis. Using a combined genetic, molecular, cellular, and biochemical approach, we have demon- 
strated that Tat adversely regulates adult neurogenesis through its alterations on NPC proliferation, migration, and differentiation. The nature of Tat being a secretory protein and readily being taken up into neighboring cells may allow Tat from astrocytes in our experimental setting to directly interact with NPCs and lead to inhibition of their proliferation (Figs. $1 A, 2,4 A-D$ ) and migration (Figs. $3 A-D, 5 A, B$ ) and to alterations in their differentiation (Figs. $3 E, F, 6 A, B$ ). Tat protein interacts with a number of cell cycle regulators or downregulates cellular genes and inhibits proliferation of various cells, including NPCs, astrocytes, and neurons (de la Fuente et al., 2002; Canani et al., 2003; Zhou and He, 2004; Nyagol et al., 2006; Toschi et al., 2006; Mishra et al., 2010; Zhang et al., 2012). Several chemokine receptors are expressed on NPCs (Ji et al., 2004), which could be engaged by chemotactic Tat protein itself (Albini et al., 1998) or chemokines induced by Tat in astrocytes (Bonwetsch et al., 1999; Kim et al., 2004; Hahn et al., 2010; Fitting et al., 2014), thus affecting NPC migration. Tat protein has also been shown to alter differentiation of mesenchymal stem cells and other cells (Zauli et al., 1994; Wang et al., 2002; Gibellini et al., 2010, 2012). However, given the extremely low level of Tat expression in the brain of iTat mice and recombinant Tat protein used in the in vitro assays, there is little if any chance that Tat affects NPCs and neurogenesis.

Notch signaling plays an essential role in neurogenesis in both the developing brain and the adult brain, including NPC proliferation, migration, and differentiation in developing and adult brains, and in neurite remodeling, synaptic plasticity, and learning and memory in the adult brain, and is involved in neurological disorders, such as neurodegenerative diseases (Ge et al., 2002; Mizutani and Saito, 2005; Miller and Gauthier, 2007; Lathia et al., 2008; Latasa et al., 2009). Our findings that Tat activates the downstream Hes1 gene of the Notch signaling pathway through direct binding (Figs. 8, 9) and that inhibition of Tat-elicited Notch signaling restores normal NPC differentiation (Figs. 10, 11) support the notion that Tat interaction with the Notch signaling pathway is mainly responsible for Tat-induced changes in NPC proliferation, migration, and differentiation, and in neurogenesis. Alternatively, Tat could regulate neurogenesis through its interaction with astrocytes, particularly in the iTat mouse model in which Tat expression is under the control of both Dox and the GFAP promoter (Kim et al., 2003) and Tat and GFAP expression form a positive feedback loop, leading to more GFAP expression or astrocytosis (Figs. 3E,F, 6). Although Tat inhibits astrocyte proliferation (Viscidi et al., 1989; Prakash et al., 2001; de la Fuente et al., 2002; Canani et al., 2003; Zhou and He, 2004; Nyagol et al., 2006), Tat activates GFAP expression through a cascade of transcriptional network (Zhou et al., 2004; Zou et al., 2010; Fan et al., 2011, 2015). Thus, it is reasonable to assume that Tat-induced astrocytosis mainly results from increased GFAP expression. In addition, the GFAP promoter is active in neural stem cells (Doetsch et al., 1999; Imura et al., 2003). Tat expression in neural stem cells could lead to more GFAP expression (Fig. 1B). Increased GFAP expression alone has been linked to reduced NPC proliferation, fewer immature neurons, and abnormal NPC differentiation and neurogenesis (Hagemann et al., 2013). It is also plausible that Tat/Notch signaling interacts with other physiologically intrinsic signaling pathways in regulating NPC proliferation, migration, differentiation, and neurogenesis. For example, bone morphogenetic proteins promote dorsal neural formation in the brain (Liu and Niswander, 2005) and interface with several pathways, such as Stat3, Wnt, and Shh, to induce astrocyte specification (Stipursky and Gomes, 2007). Stat3 induces constitutive GFAP expression and Tat-activated GFAP ex- pression (Fan et al., 2015) and promotes differentiation of neuron progenitors to astrocytes (Peng et al., 2011). Notch signaling also interfaces with Stat3 via Hes and promotes astrocyte differentiation (Bonni et al., 1997; Kamakura et al., 2004). In addition, Notch itself typically downregulates preneuronal gene expression and inhibits neuron differentiation (Bertrand et al., 2002). Thus, the Notch pathways activated by Tat binding and their exact roles in Tat-impaired neurogenesis merit further investigation.

\section{References}

Albini A, Ferrini S, Benelli R, Sforzini S, Giunciuglio D, Aluigi MG, Proudfoot AE, Alouani S, Wells TN, Mariani G, Rabin RL, Farber JM, Noonan DM (1998) HIV-1 Tat protein mimicry of chemokines. Proc Natl Acad Sci USA 95:13153-13158. CrossRef Medline

Ba K, Yang X, Wu L, Wei X, Fu N, Fu Y, Cai X, Yao Y, Ge Y, Lin Y (2012) Jagged-1-mediated activation of notch signalling induces adipogenesis of adipose-derived stem cells. Cell Prolif 45:538-544. CrossRef Medline

Belmadani A, Tran PB, Ren D, Assimacopoulos S, Grove EA, Miller RJ (2005) The chemokine stromal cell-derived factor-1 regulates the migration of sensory neuron progenitors. J Neurosci 25:3995-4003. CrossRef Medline

Belmadani A, Tran PB, Ren D, Miller RJ (2006) Chemokines regulate the migration of neural progenitors to sites of neuroinflammation. J Neurosci 26:3182-3191. CrossRef Medline

Bertrand N, Castro DS, Guillemot F (2002) Proneural genes and the specification of neural cell types. Nat Rev Neurosci 3:517-530. CrossRef Medline

Bonifaci N, Sitia R, Rubartelli A (1995) Nuclear translocation of an exogenous fusion protein containing HIV Tat requires unfolding. Aids 9:9951000. CrossRef Medline

Bonni A, Sun Y, Nadal-Vicens M, Bhatt A, Frank DA, Rozovsky I, Stahl N, Yancopoulos GD, Greenberg ME (1997) Regulation of gliogenesis in the central nervous system by the JAK-STAT signaling pathway. Science 278 : 477-483. CrossRef Medline

Bonwetsch R, Croul S, Richardson MW, Lorenzana C, Del Valle L, Sverstiuk AE, Amini S, Morgello S, Khalili K, Rappaport J (1999) Role of HIV-1 Tat and CC chemokine MIP-1alpha in the pathogenesis of HIV associated central nervous system disorders. J Neurovirol 5:685-694. CrossRef Medline

Bratanich AC, Liu C, McArthur JC, Fudyk T, Glass JD, Mittoo S, Klassen GA, Power C (1998) Brain-derived HIV-1 tat sequences from AIDS patients with dementia show increased molecular heterogeneity. J Neurovirol 4:387-393. CrossRef Medline

Brown JP, Couillard-Després S, Cooper-Kuhn CM, Winkler J, Aigner L, Kuhn HG (2003) Transient expression of doublecortin during adult neurogenesis. J Comp Neurol 467:1-10. CrossRef Medline

Canani RB, Cirillo P, Mallardo G, Buccigrossi V, Secondo A, Annunziato L, Bruzzese E, Albano F, Selvaggi F, Guarino A (2003) Effects of HIV-1 Tat protein on ion secretion and on cell proliferation in human intestinal epithelial cells. Gastroenterology 124:368-376. CrossRef Medline

Chen J, Magavi SS, Macklis JD (2004) Neurogenesis of corticospinal motor neurons extending spinal projections in adult mice. Proc Natl Acad Sci USA 101:16357-16362. CrossRef Medline

Chen P, Mayne M, Power C, Nath A (1997) The Tat protein of HIV-1 induces tumor necrosis factor-alpha production. Implications for HIV-1associated neurological diseases. J Biol Chem 272:22385-22388. CrossRef Medline

Cheng J, Nath A, Knudsen B, Hochman S, Geiger JD, Ma M, Magnuson DS (1998) Neuronal excitatory properties of human immunodeficiency virus type 1 Tat protein. Neuroscience 82:97-106. Medline

Chillakuri CR, Sheppard D, Lea SM, Handford PA (2012) Notch receptorligand binding and activation: insights from molecular studies. Semin Cell Dev Biol 23:421-428. CrossRef Medline

Conant K, Garzino-Demo A, Nath A, McArthur JC, Halliday W, Power C, Gallo RC, Major EO (1998) Induction of monocyte chemoattractant protein-1 in HIV-1 Tat-stimulated astrocytes and elevation in AIDS dementia. Proc Natl Acad Sci USA 95:3117-3121. CrossRef Medline

Cristofaro B, Shi Y, Faria M, Suchting S, Leroyer AS, Trindade A, Duarte A, Zovein AC, Iruela-Arispe ML, Nih LR, Kubis N, Henrion D, Loufrani L, Todiras M, Schleifenbaum J, Gollasch M, Zhuang ZW, Simons M, Eich- 
mann A, le Noble F (2013) Dll4-Notch signaling determines the formation of native arterial collateral networks and arterial function in mouse ischemia models. Development 140:1720-1729. CrossRef Medline

Cupp C, Taylor JP, Khalili K, Amini S (1993) Evidence for stimulation of the transforming growth factor beta 1 promoter by HIV-1 Tat in cells derived from CNS. Oncogene 8:2231-2236. Medline

Curtis K, Rollins M, Carryl H, Bradshaw K, Kimberley B, Van Rompay KK, Abel K, Burke MW (2014) Reduction of pyramidal and immature hippocampal neurons in pediatric simian immunodeficiency virus infection. Neuroreport 25:973-978. CrossRef Medline

de la Fuente C, Santiago F, Deng L, Eadie C, Zilberman I, Kehn K, Maddukuri A, Baylor S, Wu K, Lee CG, Pumfery A, Kashanchi F (2002) Gene expression profile of HIV-1 Tat expressing cells: a close interplay between proliferative and differentiation signals. BMC Biochem 3:14. CrossRef Medline

Doetsch F, Caillé I, Lim DA, García-VerdugoJM, Alvarez-Buylla A (1999) Subventricular zone astrocytes are neural stem cells in the adult mammalian brain. Cell 97:703-716. CrossRef Medline

Dubé B, Benton T, Cruess DG, Evans DL (2005) Neuropsychiatric manifestations of HIV infection and AIDS. J Psychiatry Neurosci 30:237-246. Medline

Ellis RJ, Deutsch R, Heaton RK, Marcotte TD, McCutchan JA, Nelson JA, Abramson I, Thal LJ, Atkinson JH, Wallace MR, Grant I (1997) Neurocognitive impairment is an independent risk factor for death in HIV infection. San Diego HIV Neurobehavioral Research Center Group. Arch Neurol 54:416-424. CrossRef Medline

Eng LF, Ghirnikar RS (1994) GFAP and astrogliosis. Brain Pathol 4:229237. CrossRef Medline

Epstein LG, Sharer LR, Oleske JM, Connor EM, Goudsmit J, Bagdon L, Robert-Guroff M, Koenigsberger MR (1986) Neurologic manifestations of human immunodeficiency virus infection in children. Pediatrics 78: 678-687. Medline

Falix FA, Aronson DC, Lamers WH, Gaemers IC (2012) Possible roles of DLK1 in the Notch pathway during development and disease. Biochim Biophys Acta 1822:988-995. CrossRef Medline

Fan Y, Zou W, Green LA, Kim BO, He JJ (2011) Activation of Egr-1 expression in astrocytes by HIV-1 Tat: new insights into astrocyte-mediated Tat neurotoxicity. J Neuroimmune Pharmacol 6:121-129. CrossRef Medline

Fan Y, Timani KA, He JJ (2015) STAT3 and its phosphorylation are involved in HIV-1 Tat-induced transactivation of glial fibrillary acidic protein. Curr HIV Res 13:55-63. CrossRef Medline

Fitting S, Zou S, El-Hage N, Suzuki M, Paris JJ, Schier CJ, Rodríguez JW, Rodriguez M, Knapp PE, Hauser KF (2014) Opiate addiction therapies and HIV-1 Tat: interactive effects on glial $[\mathrm{Ca}(2)(+)] \mathrm{i}$, oxyradical and neuroinflammatory chemokine production and correlative neurotoxicity. Curr HIV Res 12:424-434. Medline

Frankel AD, Pabo CO (1988) Cellular uptake of the tat protein from human immunodeficiency virus. Cell 55:1189-1193. CrossRef Medline

Fuchs E, Gould E (2000) Mini-review: in vivo neurogenesis in the adult brain: regulation and functional implications. Eur J Neurosci 12:22112214. CrossRef Medline

Gao X, Chen J (2013) Moderate traumatic brain injury promotes neural precursor proliferation without increasing neurogenesis in the adult hippocampus. Exp Neurol 239:38-48. CrossRef Medline

Ge W, Martinowich K, Wu X, He F, Miyamoto A, Fan G, Weinmaster G, Sun YE (2002) Notch signaling promotes astrogliogenesis via direct CSLmediated glial gene activation. J Neurosci Res 69:848-860. CrossRef Medline

Gibellini D, De Crignis E, Ponti C, Borderi M, Clò A, Miserocchi A, Viale P, Re MC (2010) HIV-1 Tat protein enhances RANKL/M-CSF-mediated osteoclast differentiation. Biochem Biophys Res Comm 401:429-434. CrossRef Medline

Gibellini D, Miserocchi A, Tazzari PL, Ricci F, Clò A, Morini S, Ponti C, Pasquinelli G, Bon I, Pagliaro P, Borderi M, Re MC (2012) Analysis of the effects of HIV-1 Tat on the survival and differentiation of vessel wallderived mesenchymal stem cells. J Cell Biochem 113:1132-1141. CrossRef Medline

Hagemann TL, Paylor R, Messing A (2013) Deficits in adult neurogenesis, contextual fear conditioning, and spatial learning in a Gfap mutant mouse model of Alexander disease. J Neurosci 33:18698-18706. CrossRef Medline

Hahn YK, Vo P, Fitting S, Block ML, Hauser KF, Knapp PE (2010) beta-
Chemokine production by neural and glial progenitor cells is enhanced by HIV-1 Tat: effects on microglial migration. J Neurochem 114:97-109. CrossRef Medline

Hofman FM, Chen P, Incardona F, Zidovetzki R, Hinton DR (1999) HIV-1 tat protein induces the production of interleukin- 8 by human brainderived endothelial cells. J Neuroimmunol 94:28-39. CrossRef Medline

Huang X, Kong H, Tang M, Lu M, Ding JH, Hu G (2012) D-Serine regulates proliferation and neuronal differentiation of neural stem cells from postnatal mouse forebrain. CNS Neurosci Ther 18:4-13. CrossRef Medline

Imura T, Kornblum HI, Sofroniew MV (2003) The predominant neural stem cell isolated from postnatal and adult forebrain but not early embryonic forebrain expresses GFAP. J Neurosci 23:2824-2832. Medline

Iosif RE, Ekdahl CT, Ahlenius H, Pronk CJ, Bonde S, Kokaia Z, Jacobsen SE, Lindvall O (2006) Tumor necrosis factor receptor 1 is a negative regulator of progenitor proliferation in adult hippocampal neurogenesis. J Neurosci 26:9703-9712. CrossRef Medline

Jeeninga RE, Hoogenkamp M, Armand-Ugon M, de Baar M, Verhoef K, Berkhout B (2000) Functional differences between the long terminal repeat transcriptional promoters of human immunodeficiency virus type 1 subtypes A through G. J Virol 74:3740-3751. CrossRef Medline

Ji JF, He BP, Dheen ST, Tay SS (2004) Expression of chemokine receptors CXCR4, CCR2, CCR5 and CX3CR1 in neural progenitor cells isolated from the subventricular zone of the adult rat brain. Neurosci Lett 355: 236-240. CrossRef Medline

Johnson TP, Patel K, Johnson KR, Maric D, Calabresi PA, Hasbun R, Nath A (2013) Induction of IL-17 and nonclassical T-cell activation by HIV-Tat protein. Proc Natl Acad Sci USA 110:13588-13593. CrossRef Medline

Jones M, Olafson K, Del Bigio MR, Peeling J, Nath A (1998) Intraventricular injection of human immunodeficiency virus type 1 (HIV-1) tat protein causes inflammation, gliosis, apoptosis, and ventricular enlargement. J Neuropathol Exp Neurol 57:563-570. CrossRef Medline

Kageyama R, Ohtsuka T (1999) The Notch-Hes pathway in mammalian neural development. Cell Res 9:179-188. CrossRef Medline

Kamakura S, Oishi K, Yoshimatsu T, Nakafuku M, Masuyama N, Gotoh Y (2004) Hes binding to STAT3 mediates crosstalk between Notch and JAK-STAT signalling. Nat Cell Biol 6:547-554. CrossRef Medline

Kaul M, Garden GA, Lipton SA (2001) Pathways to neuronal injury and apoptosis in HIV-associated dementia. Nature 410:988-994. CrossRef Medline

Kaul M, Zheng J, Okamoto S, Gendelman HE, Lipton SA (2005) HIV-1 infection and AIDS: consequences for the central nervous system. Cell Death Differ 12 [Suppl 1]:878-892. CrossRef Medline

Kim BO, Liu Y, Ruan Y, Xu ZC, Schantz L, He JJ (2003) Neuropathologies in transgenic mice expressing human immunodeficiency virus type 1 Tat protein under the regulation of the astrocyte-specific glial fibrillary acidic protein promoter and doxycycline. Am J Pathol 162:1693-1707. CrossRef Medline

Kim BO, Liu Y, Zhou BY, He JJ (2004) Induction of C chemokine XCL1 (lymphotactin/single $\mathrm{C}$ motif- 1 alpha/activation-induced, $\mathrm{T}$ cell-derived and chemokine-related cytokine) expression by HIV-1 Tat protein. J Immunol 172:1888-1895. CrossRef Medline

Klaver B, Berkhout B (1994) Comparison of 5' and 3' long terminal repeat promoter function in human immunodeficiency virus. J Virol 68:3830 3840. Medline

Kolson DL, Buchhalter J, Collman R, Hellmig B, Farrell CF, Debouck C, Gonzalez-Scarano F (1993) HIV-1 Tat alters normal organization of neurons and astrocytes in primary rodent brain cell cultures: RGD sequence dependence. AIDS Res Hum Retroviruses 9:677-685. CrossRef Medline

Krathwohl MD, Kaiser JL (2004a) HIV-1 promotes quiescence in human neural progenitor cells. J Infect Dis 190:216-226. CrossRef Medline

Krathwohl MD, Kaiser JL (2004b) Chemokines promote quiescence and survival of human neural progenitor cells. Stem Cells 22:109-118. CrossRef Medline

Latasa MJ, Cisneros E, Frade JM (2009) Cell cycle control of Notch signaling and the functional regionalization of the neuroepithelium during vertebrate neurogenesis. Int J Dev Biol 53:895-908. CrossRef Medline

Lathia JD, Mattson MP, Cheng A (2008) Notch: from neural development to neurological disorders. J Neurochem 107:1471-1481. CrossRef Medline

Lawrence DM, Durham LC, Schwartz L, Seth P, Maric D, Major EO (2004) 
Human immunodeficiency virus type 1 infection of human brain-derived progenitor cells. J Virol 78:7319-7328. CrossRef Medline

Lee J, Duan W, Mattson MP (2002) Evidence that brain-derived neurotrophic factor is required for basal neurogenesis and mediates, in part, the enhancement of neurogenesis by dietary restriction in the hippocampus of adult mice. J Neurochem 82:1367-1375. CrossRef Medline

Leuner B, Gould E, Shors TJ (2006) Is there a link between adult neurogenesis and learning? Hippocampus 16:216-224. CrossRef Medline

Liu A, Niswander LA (2005) Bone morphogenetic protein signalling and vertebrate nervous system development. Nat Rev Neurosci 6:945-954. CrossRef Medline

Liu Y, Jones M, Hingtgen CM, Bu G, Laribee N, Tanzi RE, Moir RD, Nath A, He JJ (2000) Uptake of HIV-1 tat protein mediated by low-density lipoprotein receptor-related protein disrupts the neuronal metabolic balance of the receptor ligands. Nat Med 6:1380-1387. CrossRef Medline

Liu Y, Li J, Kim BO, Pace BS, He JJ (2002) HIV-1 Tat protein-mediated transactivation of the HIV-1 long terminal repeat promoter is potentiated by a novel nuclear Tat-interacting protein of $110 \mathrm{kDa}$, Tip110. J Biol Chem 277:23854-23863. CrossRef Medline

Liu Z, Zhao F, He JJ (2014) Hepatitis C virus (HCV) interaction with astrocytes: nonproductive infection and induction of IL-18. J Neurovirol 20: 278-293. CrossRef Medline

Lledo PM, Alonso M, Grubb MS (2006) Adult neurogenesis and functional plasticity in neuronal circuits. Nat Rev Neurosci 7:179-193. CrossRef Medline

Mann DA, Frankel AD (1991) Endocytosis and targeting of exogenous HIV-1 Tat protein. EMBO J 10:1733-1739. Medline

Mignone JL, Kukekov V, Chiang AS, Steindler D, Enikolopov G (2004) Neural stem and progenitor cells in nestin-GFP transgenic mice. J Comp Neurol 469:311-324. CrossRef Medline

Miller FD, Gauthier AS (2007) Timing is everything: making neurons versus glia in the developing cortex. Neuron 54:357-369. CrossRef Medline

Ming GL, Song H (2005) Adult neurogenesis in the mammalian central nervous system. Annu Rev Neurosci 28:223-250. CrossRef Medline

Mishra M, Vetrivel S, Siddappa NB, Ranga U, Seth P (2008) Clade-specific differences in neurotoxicity of human immunodeficiency virus-1 B and C Tat of human neurons: significance of dicysteine C30C31 motif. Ann Neurol 63:366-376. CrossRef Medline

Mishra M, Taneja M, Malik S, Khalique H, Seth P (2010) Human immunodeficiency virus type 1 Tat modulates proliferation and differentiation of human neural precursor cells: implication in NeuroAIDS. J Neurovirol 16:355-367. CrossRef Medline

Mizutani K, Saito T (2005) Progenitors resume generating neurons after temporary inhibition of neurogenesis by Notch activation in the mammalian cerebral cortex. Development 132:1295-1304. CrossRef Medline

Moors M, Cline JE, Abel J, Fritsche E (2007) ERK-dependent and -independent pathways trigger human neural progenitor cell migration. Toxicol Appl Pharmacol 221:57-67. CrossRef Medline

Netzer WJ, Powell C, Nong Y, Blundell J, Wong L, Duff K, Flajolet M, Greengard P (2010) Lowering beta-amyloid levels rescues learning and memory in a Down syndrome mouse model. PLoS One 5:e10943. CrossRef Medline

Nyagol J, Leucci E, Onnis A, De Falco G, Tigli C, Sanseverino F, Torriccelli M, Palummo N, Pacenti L, Santopietro R, Spina D, Gichangi P, Muchiri L, Lazzi S, Petraglia F, Leoncini L, Giordano A (2006) The effects of HIV-1 Tat protein on cell cycle during cervical carcinogenesis. Cancer Biol Ther 5:684-690. CrossRef Medline

Okamoto S, Kang YJ, Brechtel CW, Siviglia E, Russo R, Clemente A, Harrop A, McKercher S, Kaul M, Lipton SA (2007) HIV/gp120 decreases adult neural progenitor cell proliferation via checkpoint kinase-mediated cellcycle withdrawal and G1 arrest. Cell Stem Cell 1:230-236. CrossRef Medline

Paris JJ, Carey AN, Shay CF, Gomes SM, He JJ, McLaughlin JP (2014) Effects of conditional central expression of HIV-1 tat protein to potentiate cocaine-mediated psychostimulation and reward among male mice. Neuropsychopharmacology 39:380-388. CrossRef Medline

Parmentier HK, van Wichen DF, Meyling FH, Goudsmit J, Schuurman HJ (1992) Epitopes of human immunodeficiency virus regulatory proteins tat, nef, and rev are expressed in normal human tissue. Am J Pathol 141:1209-1216. Medline

Peng H, Whitney N, Wu Y, Tian C, Dou H, Zhou Y, Zheng J (2008) HIV1-infected and/or immune-activated macrophage-secreted TNF-alpha affects human fetal cortical neural progenitor cell proliferation and differentiation. Glia 56:903-916. CrossRef Medline

Peng H, Sun L, Jia B, Lan X, Zhu B, Wu Y, Zheng J (2011) HIV-1-infected and immune-activated macrophages induce astrocytic differentiation of human cortical neural progenitor cells via the STAT3 pathway. PLoS One 6:e19439. CrossRef Medline

Poluektova L, Meyer V, Walters L, Paez X, Gendelman HE (2005) Macrophage-induced inflammation affects hippocampal plasticity and neuronal development in a murine model of HIV-1 encephalitis. Glia 52:344-353. CrossRef Medline

Prakash O, Rodriguez VE, Tang ZY, Zhou P, Coleman R, Dhillon G, Shellito JE, Nelson S (2001) Inhibition of hematopoietic progenitor cell proliferation by ethanol in human immunodeficiency virus type 1 tatexpressing transgenic mice. Alcohol Clin Exp Res 25:450-456. CrossRef Medline

Ranga U, Shankarappa R, Siddappa NB, Ramakrishna L, Nagendran R, Mahalingam M, Mahadevan A, Jayasuryan N, Satishchandra P, Shankar SK, Prasad VR (2004) Tat protein of human immunodeficiency virus type 1 subtype C strains is a defective chemokine. J Virol 78:2586-2590. CrossRef Medline

Rodríguez P, Higueras MA, González-Rajal A, Alfranca A, Fierro-Fernández M, García-Fernández RA, Ruiz-Hidalgo MJ, Monsalve M, RodríguezPascual F, Redondo JM, de la Pompa JL, Laborda J, Lamas S (2012) The noncanonical NOTCH ligand DLK1 exhibits a novel vascular role as a strong inhibitor of angiogenesis. Cardiovasc Res 93:232-241. CrossRef Medline

Sairanen M, Lucas G, Ernfors P, Castrén M, CastrénE (2005) Brain-derived neurotrophic factor and antidepressant drugs have different but coordinated effects on neuronal turnover, proliferation, and survival in the adult dentate gyrus. J Neurosci 25:1089-1094. CrossRef Medline

Schwartz L, Major EO (2006) Neural progenitors and HIV-1-associated central nervous system disease in adults and children. Curr HIV Res 4:319-327. CrossRef Medline

Shikatani EA, Trifonova A, Mandel ER, Liu ST, Roudier E, Krylova A, Szigiato A, Beaudry J, Riddell MC, Haas TL (2012) Inhibition of proliferation, migration and proteolysis contribute to corticosterone-mediated inhibition of angiogenesis. PLoS One 7:e46625. CrossRef Medline

Shoham N, Cohen L, Yaniv A, Gazit A (2003a) The Tat protein of the human immunodeficiency virus type 1 (HIV-1) interacts with the EGF-like repeats of the Notch proteins and the EGF precursor. Virus Res 98:57-61. CrossRef Medline

Shoham N, Cohen L, Gazit A, Yaniv A (2003b) The Tat protein of the caprine arthritis encephalitis virus interacts with the Notch2 EGF-like repeats and the epithelin/granulin precursor. Intervirology 46:239-244. CrossRef Medline

Stipursky J, Gomes FC (2007) TGF-beta1/SMAD signaling induces astrocyte fate commitment in vitro: implications for radial glia development. Glia 55:1023-1033. CrossRef Medline

Toschi E, Bacigalupo I, Strippoli R, Chiozzini C, Cereseto A, Falchi M, Nappi F, Sgadari C, Barillari G, Mainiero F, Ensoli B (2006) HIV-1 Tat regulates endothelial cell cycle progression via activation of the Ras/ERK MAPK signaling pathway. Mol Biol Cell 17:1985-1994. CrossRef Medline

Tran PB, Ren D, Miller RJ (2005) The HIV-1 coat protein gp120 regulates CXCR4-mediated signaling in neural progenitor cells. J Neuroimmunol 160:68-76. CrossRef Medline

Valcour VG, Shikuma CM, Watters MR, Sacktor NC (2004) Cognitive impairment in older HIV-1-seropositive individuals: prevalence and potential mechanisms. Aids 18 [Suppl 1]:S79-S86. Medline

Vallières L, Campbell IL, Gage FH, Sawchenko PE (2002) Reduced hippocampal neurogenesis in adult transgenic mice with chronic astrocytic production of interleukin-6. J Neurosci 22:486-492. Medline

Viscidi RP, Mayur K, Lederman HM, Frankel AD (1989) Inhibition of antigen-induced lymphocyte proliferation by Tat protein from HIV-1. Science 246:1606-1608. CrossRef Medline

Wang L, Mondal D, La Russa VF, Agrawal KC (2002) Suppression of clonogenic potential of human bone marrow mesenchymal stem cells by HIV type 1: putative role of HIV type 1 tat protein and inflammatory cytokines. AIDS Res Hum Retroviruses 18:917-931. CrossRef Medline

Westendorp MO, Frank R, Ochsenbauer C, Stricker K, Dhein J, Walczak H, Debatin KM, Krammer PH (1995) Sensitization of T cells to CD95mediated apoptosis by HIV-1 Tat and gp120. Nature 375:497-500. CrossRef Medline 
Whitney NP, Eidem TM, Peng H, Huang Y, Zheng JC (2009) Inflammation mediates varying effects in neurogenesis: relevance to the pathogenesis of brain injury and neurodegenerative disorders. J Neurochem 108:13431359. CrossRef Medline

Xiao H, Neuveut C, Tiffany HL, Benkirane M, Rich EA, Murphy PM, Jeang KT (2000) Selective CXCR4 antagonism by Tat: implications for in vivo expansion of coreceptor use by HIV-1. Proc Natl Acad Sci USA 97:1146611471. CrossRef Medline

Xie L, Choudhury GR, Wang J, Park Y, Liu R, Yuan F, Zhang CL, Yorio T, Jin K, Yang SH (2014) Methylene blue promotes quiescence of rat neural progenitor cells. Front Cell Neurosci 8:315. CrossRef Medline

Yao H, Duan M, Yang L, Buch S (2012) Platelet-derived growth factor-BB restores human immunodeficiency virus Tat-cocaine-mediated impairment of neurogenesis: role of TRPC1 channels. J Neurosci 32:9835-9847. CrossRef Medline

Zauli G, Marchisio M, Bertagnolo V, Celeghini C, Capitani S (1994) Hiv-1 tat protein suppresses the nerve growth-factor (ngf)-mediated differentiation of PC12 rat pheochromocytoma cell-line. Oncol Rep 1:773-777. Medline

Zhang SM, Song M, Yang TY, Fan R, Liu XD, Zhou PK (2012) HIV-1 Tat impairs cell cycle control by targeting the Tip60, Plk1 and cyclin B1 ternary complex. Cell Cycle 11:1217-1234. CrossRef Medline

Zhou BY, He JJ (2004) Proliferation inhibition of astrocytes, neurons, and non-glial cells by intracellularly expressed human immunodeficiency virus type 1 (HIV-1) Tat protein. Neurosci Lett 359:155-158. CrossRef Medline

Zhou BY, Liu Y, Kim BO, Xiao Y, He JJ (2004) Astrocyte activation and dysfunction and neuron death by HIV-1 Tat expression in astrocytes. Mol Cell Neurosci 27:296-305. CrossRef Medline

Zidovetzki R, Wang JL, Chen P, Jeyaseelan R, Hofman F (1998) Human immunodeficiency virus Tat protein induces interleukin 6 mRNA expression in human brain endothelial cells via protein kinase C- and cAMPdependent protein kinase pathways. AIDS Res Hum Retroviruses 14: 825-833. CrossRef Medline

Zou W, Kim BO, Zhou BY, Liu Y, Messing A, He JJ (2007) Protection against human immunodeficiency virus type 1 Tat neurotoxicity by Ginkgo biloba extract EGb 761 involving glial fibrillary acidic protein. Am J Pathol 171:1923-1935. CrossRef Medline

Zou W, Wang Z, Liu Y, Fan Y, Zhou BY, Yang XF, He JJ (2010) Involvement of p300 in constitutive and HIV-1 Tat-activated expression of glial fibrillary acidic protein in astrocytes. Glia 58:1640-1648. CrossRef Medline 